NBSIR 78-1143A

Supersedes NBSIR 76-1143

\title{
Plan for the Development and Implementation of Standards for Solar Heating and Cooling Applications
}

D. Waksman, J.H. Pielert, R.D. Dikkers, E.R. Streed, W.J. Niessing

Center for Building Technology National Engineering Laboratory National Bureau of Standards

Washington, D.C. 20234

June 1978

(First Revision of NBSIR 76-1143)

Prepared for

Department of Energy Office of the Assistant Secretary Conservation and Solar Applications Washington, D.C. 20545

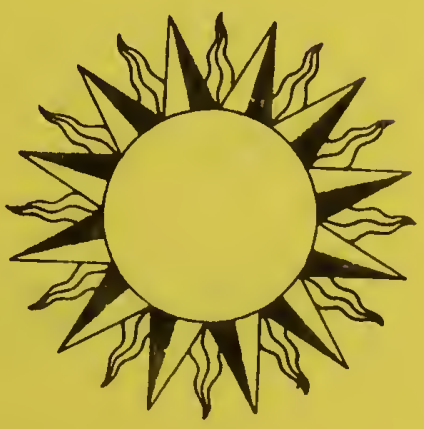





\section{PLAN FOR THE DEVELOPMENT AND IMPLEMENTATION OF STANDARDS FOR SOLAR HEATING AND COOLING APPLICATIONS}

D. Waksman, J.H. Pielert, R.D. Dikkers,

E.R Streed, W.J. Niessing

Center for Building Technology National Engineering Laboratory National Bureau of Standards

Washington, D.C. 20234

June 1978

(First Revisıon of NBSIR 76-1143)

Prepared for

Department of Energy

Office of the Assistant Secretary

Conservation and Solar Applications

Washington, D.C. 20545

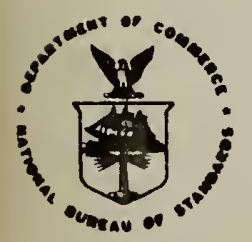

U.S. DEPARTMENT OF COMMERCE, Juanita M. Kreps, Secretary

Dr. Sidney Harman, Under Secrotary

Jordan J. Baruch, Assistant Socrotary for Scionce and Technology

NATIONAL BUREAU OF STANDARDS, Emest Ambler, Diroctor 



\section{FOREWORD}

The primary goal of the National Program for Solar Heating and Cooling of Buildings is "to work with industry in the development and early introduction of economically competitive and environmentally acceptable solar energy systems to help meet National energy requirements To help achieve this goal, it will be necessary to establish standards; i.e., safety, thermal performance, durability/reliability, for solar heating and cooling equipment.

This edition of the standards plan is the first revision of a plan issued by the National Bureau of Standards in September 1976 as NBSIR 76-1143, "P1an for the Development and Implementation of Standards for Solar Heating and Cooling Applications." The revisions made to the tables in the original plan represent input from the ANSI Steering Committee on Solar Energy Standards Development. The tables in Section VII were approved by the ANSI Committee on Apri1 12, 1978.

The purpose of this report is to identify needed standards and to help coordinate their development and implementation on a systematic basis. It is expected that this report will be revised on an "as needed" basis in order to update the status of solar standards development activities. Comments concerning corrections, additions, related organizational activities, schedules, etc., are invited and will be reviewed and considered for incorporation in a future update of this report. Comments should be sent to:

Chief, Solar Criteria and Standards Program

National Bureau of Standards

Building 225, Room A-114

Washington, D.C. 20234 


\section{ACKNOWLEDGMENT}

The authors would like to thank the many individuals and organizations who provided comments and review of the initial version of this publication, NBSIR 76-1143. In particular, the many helpful suggestions provided by Carl W. Conner and Ronald D. Scott of the Department of Energy, William Freeborne and David Moore of the Department of Housing and Urban Development and various members of the ANSI Steering Committee on Solar Energy Standards Development (refer to Appendix A for list of members and alternates) are gratefully acknowledged.

For this first revision of the Standards Implementation Plan the efforts of the various members of the ANSI Steering Committee and, particularly, the three Subcommittee Chairmen, Messrs. A. Newton, A. Baldwin, and E. A. Kuhn, are gratefully acknowledged. 



\section{INTRODUCTION}

Justification for Development and Implementation of Solar Standards

Sections 5 and 6 of Public Law 93-409, the "Solar Heating and Cooling Demonstration Act of 1974 " provide for the development of

1. interim performance criteria for solar heating and combined solar heating and cooling components and systems to be used in residential dwellings, and

2. interim performance criteria (relating to suitability for solar heating and combined solar heating and cooling) for such dwellings themselves.

These criteria are primarily intended for use in the Department of Housing and Urban Development (HUD) residential demonstration program.

Section 8 of the Act provides for the development "as soon as feasible, and utilizing data available from the demonstration programs under Sections 5 and $6^{\prime \prime}$ of

1. definitive performance criteria for solar heating and combined heating and cooling components and systems to be used in residential dwellings, taking into account climatic variations existing between different geographic areas;

2. definitive performance criteria (relating to suitability for solar heating and combined solar heating and cooling) for such dwellings, taking into account climatic variations existing between different geographic areas; and

3. procedures whereby manufacturers of solar heating and combined solar heating and cooling components and systems shall have their products tested in order to provide certification that such products conform to the performance criteria established under paragraph 1.

In order to comply with the intent of PL 93-409, the "National Program for Solar Heating and Cooling (Residential and Commercial Applications)," ERDA-23A [1]* was prepared and published in October 1975. The first Annual Program Report for the National Program which was published as ERDA 76-6 [2] in November 1976 reflects the results of continuing assessment of initial plans, additional program planning activities, and experience gained in the past year by program participants. With regard to standards and their implementation for solar heating and cooling applications, ERDA 76-6 includes the following program objectives:

"o Develop solar energy system performance standards and criteria for the production and installation of solar energy systems, subsystems and components, with appropriate provisions for consumer protection;

- Identify and promulgate the necessary legislation, codes and incentives to mitigate or eliminate existing legal or institutional restrictions which may discourage the development of solar energy;

- Develop design guidelines for solar heating and cooling systems, subsystems and components; and

o Assure early availability of accredited private sector testing facilities."

Specific tasks relating to the establishment of performance criteria and standards are described in ERDA $76-6$ in order to help meet these objectives.

*Brackets indicate references 1 isted on pages 48,49 , and 50 . 
As outlined above, the "National Program for Solar Heating and Cooling" clearly recognizes the importance and needs of standards to help stimulate the creation of a viable industrial and commercial capability to produce and distribute solar heating and cooling systems. Because of the worldwide interest in applications for solar systems, standards development should be coordinated with international groups to provide a common basis for world trade.

More specifically, standards for solar heating and cooling systems and components are needed to establish acceptable minimum requirements for health and safety as well as acceptable minimum levels of technical performance; e.g. thermal performance, durability/reliability, etc. Such minimum requirements and levels of technical performance are also desirable for purposes of consumer acceptance, mortgage insurance, tax credit or incentive programs, and industry commercialization. It is expected that the aforementioned definitive performance criteria, along with other solar standards, will serve as the basis for model state and local building codes as well as for Federal specifications. Therefore, it is desirable that the definitive standards be nationally accepted as voluntary consensus standards that can be used for the evaluation and certification of solar equipment.

B. Purpose of P1an

The purpose of this plan is to present background information concerning the need, implementation, general scope and status of standards which may be required for solar heating and cooling applications, and to outline and discuss recommended actions which should be taken for the early development and implementation of draft and national consensus standards for solar heating and cooling systems, subsystems, components and materials.

The scope of the standards for solar heating and cooling applications must ensure that the technical, fabrication, institutional and operational requirements of the various professional, trade, regulatory and consumer groups are accommodated in a timely and economical manner. The essential functional, performance and operational requirements were initially identified by extensive feasibility Phase 0 studies [3] conducted for the National Science Foundation.

The importance of developing performance-based standards, rather than prescriptive standards, cannot be overemphasized. A report to the Ford Foundation, New Energy Technologies for Buildings, Shoen, et al [4], analyzed past fallures in introducing new technologies into the building industry and indicated how failures can be avolded through the use of such a system of standards.

C. Content of Plan

This plan contains overviews of the various types of standards that are presently avallable (Section II), how standards are normally developed in the United States (Section III), and how these standards are normally utilized by the building regulatory system (Section IV) as background information.

Recommendations are included regarding actions and steps that should be taken to identify available and needed solar standards (Section V); current activities in both the public and private sectors related to solar standards are discussed (Section V); activities related to the implementation of solar standards are presented (Section VI); and tables which can be used to coordinate the development and implementation of standards for heating and cooling applications are included (Section VII). 
It is highly important that this plan be continually updated in consultation with interested members of the building community, and implemented so that needed draft standards and national consensus standards can be developed, or existing standards revised, in order to aid architects, engineers, manufacturers, regulatory agencies, financial institutions, builders, consumers and other members of the building community in the acceptance (design, evaluation, and installation) of solar heating and cooling systems, subsystems and components. The identification of standards needs on a systematic basis will require consideration of previous solar experiences and experience gained in related fields; e.g., heating, ventilating and air-conditioning (HVAC). It will also be important to coordinate standards development activities to ensure the timely and efficient development of solar standards; avoiding both gaps and duplication of efforts. 


\section{OVERVIEW OF STANDARDS}

A building standard is a specific requirement or instruction for the design, manufacture, installation and use of a building component, system, or material that will provide an acceptable level of performance under in-use conditions. A standard exists when an agreement has been obtained on its content. The level of agreement ranges from a small group of interested parties to national or international standards which have been developed through the consensus process.

Consensus standards supplement building codes whether they be model codes, State codes or local codes. The most widely accepted method of this utilization is to reference standards in the appendix of the code and then to spell out the condition of their applicability in the text of the code. As an example of the dependence of building codes on standards, the Basic Building Code [5] references over 400 standards. There ave over 400 organizations in this country developing building standards which are used 10 ovar 1000 different building codes. These include trade associations,-engineering societies testing laboratories, building code organizations, government agencies and manufacturers.

A. Types of Standards

The definitions for the various types of standards developed by the American Society for Testing and Materials (ASTM), which follow, were used in this solar standards development and implementation plan. It is recognized that other standards developing organizations such as American Society of Mechanical Engineers (ASME), Underwriters Laboratory, Inc. (UL), American Society for Heating, Refrigerating, and Air-Conditioning Engineers, Inc. (ASHRAE), etc. produce similar types of standards which may have different names.

ASTM produces four major types of standards defined as follows [6].

1. Specification - "a form of standard that is a precise statement of a set of requirements to be satisfied by a material, product, system, or service, indicating whenever appropriate, the procedure by means of which it may be determined whether the requirements given are satisfied. As far as practicable, it is desirable that the requirements be expressed numerically in terms of appropriate units together with their limits."

An example of a specification standard is ASTM B135, "Specification of Seamless Brass Tube."

2. Test Method - "a form of standard that covers sampling and describes the subsequent testing procedures used in determining the properties, composition, or performance for materials, products, systems, or services that may be specified. A test method shall not include the kind of numerical limits for the properties, composition, or performance that should normally be included in a specification."

An example of this type of standard is ASTM E119, "Standard Method of Fire Tests of Building Construction and Materials." This standard given procedures for evaluating structural response during and after the test and the passage of heat, smoke and fire but does not give acceptable limits for each. These are usually provided in the provisions of the building code.

3. Classification - "a form of standard that defines a systematic arrangement or division of materials, products, systems, or services, into groups based on similar characteristics such as origin, composition, properties, or use."

4. Definition - "a form of standard that comprises one or more terms with explanation of Its meaning as applied to materials, products, systems, services, and methods within the scopes of technical committees.

An example of a definition standard is ASTM E349-72, "Definition of Terms Relating to Space Simulation." 
5. Practice - "a form of standard that is a procedure, guide, or service which may or may not be auxiliary to a test method or a specification. Examples of such include selection, preparation, application, inspection, necessary precautions for use of disposal, installation, maintenance, and operation of testing apparatus."

An example of an existing practice standard is ASTM D2855, "Recommended Practice for Making Solvent - Comented Joints with Poly (Vinyl Chloride)(PVC) Pipe and Fittings."

Performance vs. Prescriptive Standards

A prescriptive standard is quite specific in nature giving details of usage or design procedures for a building material, component or system. An example of a prescriptive requirement would be that timber wall framing shall be $2 \times 4$ studs on 16-inch centers. A performance standard prescribes objectives, conditions and criteria to be accomplished and allows broad leeway for the designer to achieve results [7]. The performance statement for the above condition would be that the wall system shall be designed to specified loading and deformation criteria allowing the innovative designer freedom to select the materials and other specific construction details.

In some cases, true performance codes (and standards) are difficult to administer and most codes combine performance criteria and prescriptive requirements. As an example, the model building codes normally contain general statements of performance objectives for the various elements of the building followed by a description of acceptable ways to build that element, or use a given material, or a reference to a national standard which in itself is a specification. This provides broad opportunities for the innovative designer while simplifying the design and use of conventional materials.

Voluntary Standards Developing System

Most national standards in the United States are produced through a "voluntary system" made up of government and industry, producers and consumers, institutions, and individuals. The system is called "voluntary" since participation of interested parties is on a voluntary basis and the standards produced are intended for use within building regulations.

The consensus concept has become quite important in the voluntary standards generating process to ensure that the standards produced have widespread acceptance and use. ASTM defines a consensus standard as: "a standard produced by a body selected, organized, and conducted in accordance with the procedural standards of 'due process.' In standards development practice, a consensus is achieved when substantial agreement is reached by concerned interests according to the judgment of a duly-appointed review authority" [8]. The standards of "due process" include an adequate notice of proposed standard undertaking to all persons likely to be affected, opportunity for wide participation of affected interests in meetings, adequate maintenance and distribution of meeting records, timely reports on ballots, attention to minority opinions, and other such requirements.

\section{Federal Standards}

The increasing Federal government involvement in the problems of housing, urban development and energy are having an increasing impact on building standards and codes and their administration. The result is a series of building standards, some of which are mandatory in nature. These standards incorporate and reference many other standards

1. FHA Minimum Property Standards (MPS) - Faced with the necessity of applying common criteria for underwriting mortgage loan insurance on housing on a nationwide basis, the Federal Housing Administration (FHA) began development of its own set of minimum standards for new residential housing in 1934. The MPS were published in 1940 for multifamily projects and in 1942 for single-family dwellings [9]. The MPS apply to housing which is constructed under the FHA mortgage loan insurance program. 
The MPS have played a small role in the development of building code requirements since the FHA has never promoted them as a substitute for local building codes. However, the MPS have played a major role in shaping the design of residential housing since builders naturally shaped their designs to meet MPS requirements, even if they were not intended for inclusion under the FHA mortgage load insurance program. The FHA "Use of Materials Bulletins," which signify FHA's approvals of new materials for housing, have become a major checkpoint for the introduction of new materials. The Veterans Administration and Farmers Home Administration require that homes included under their mortgage insurance programs comply with the FHA MPS.

2. Occupational Safety and Health Act - The Federal Occupational Safety and Health Act of 1970 authorized the Secretary of Labor to promulgate national health and safety standards applicable to places of employment. The national standard applies to the construction phase of all residential dwellings. However, OSHA's major impact is on commercial and industrial properties, not residential.

3. Federal Mobile Home Standard - Title VI of the "Housing and Community Development Act of 1974" (PL 93-383) authorized the Department of Housing and Urban Development (HUD) to regulate the construction of mobile homes in this country. HUD has issued uniform construction and safety standards, which became mandatory on June 15, 1976, for the structural, plumbing, mechanical and electrical elements of residential mobile homes [10]. These standards preempt all state and local requirements. While HUD is also charged with enforcing the standard, it has contracted with the National Conference of States on Building Codes and Standards (NCSBCS), Inc. to provide support in carrying out those enforcement responsibilities. 


\section{STANDARDS DEVELOPMENT}

\section{Organizations Involved}

The organizations in this country developing building standards include trade associations (American Gas Association, American Iron and Steel Institute, etc.), engineering societies (ASHRAE, ASME, etc.), testing laboratories (UL, Factory Mutual, etc.), building code organizations (BOCA, ICBO, SBCC, etc.), Federal Government (Department of Commerce, Department of Labory etc.) and manufacturers. A Department of Commerce publication [11] lists the standards generating committees presently operating in the United States.

The American Society for Testing and Materials (ASTM) develops and publishes standard specifications for materials and standard methods of testing materials and assemblies. The National Fire Protection Association (NFPA) develops and publishes fire protection, fire prevention and fire safety standards. The American National Standards Institute (ANSI) serves as the coordinating agency for the approval of standards produced by other recognized authoritative agencies and, in some cases, develops standards.

The establishment of the National Institute of Building Science (NIBS) was authorized by the Housing and Community Development Act of 1974 (PL 93-383). NIBS was established "to encourage and provide for the maximum participation feasible of public and private scientific, technical, and financial organizations, institutions, and agencies now engaged in activities pertinent to the development, promulgation, and maintenance of performance criteria, standards, and other technical provisions for building codes and other regulations." A Board of Directors was appointed by the President in September 1976. NIBS has received its first capital funds appropriation from Congress for FY 78 and has established permanent offices in Washington; D.C. An initial activity of NIBS has been participation in an NBS program to develop interim solar energy code provisions.

\section{Standards Development Process}

Most of the standards development organizations in the United States have well established procedures for their standards development operations. Practically all of these procedures set forth some form of due process, ensure some type of consensus, and give some special consideration to minority veting positions. The general process in the development of a consensus standards is illustrated in figure 1 . It is desirable that the voting body be representative of the various interested groups in the building community who are concerned with the standards developed. See reference [8] for a discussion of procedures for standards development of the various major organizations in this country. 


\section{CONSENSUS \\ STANDARD}

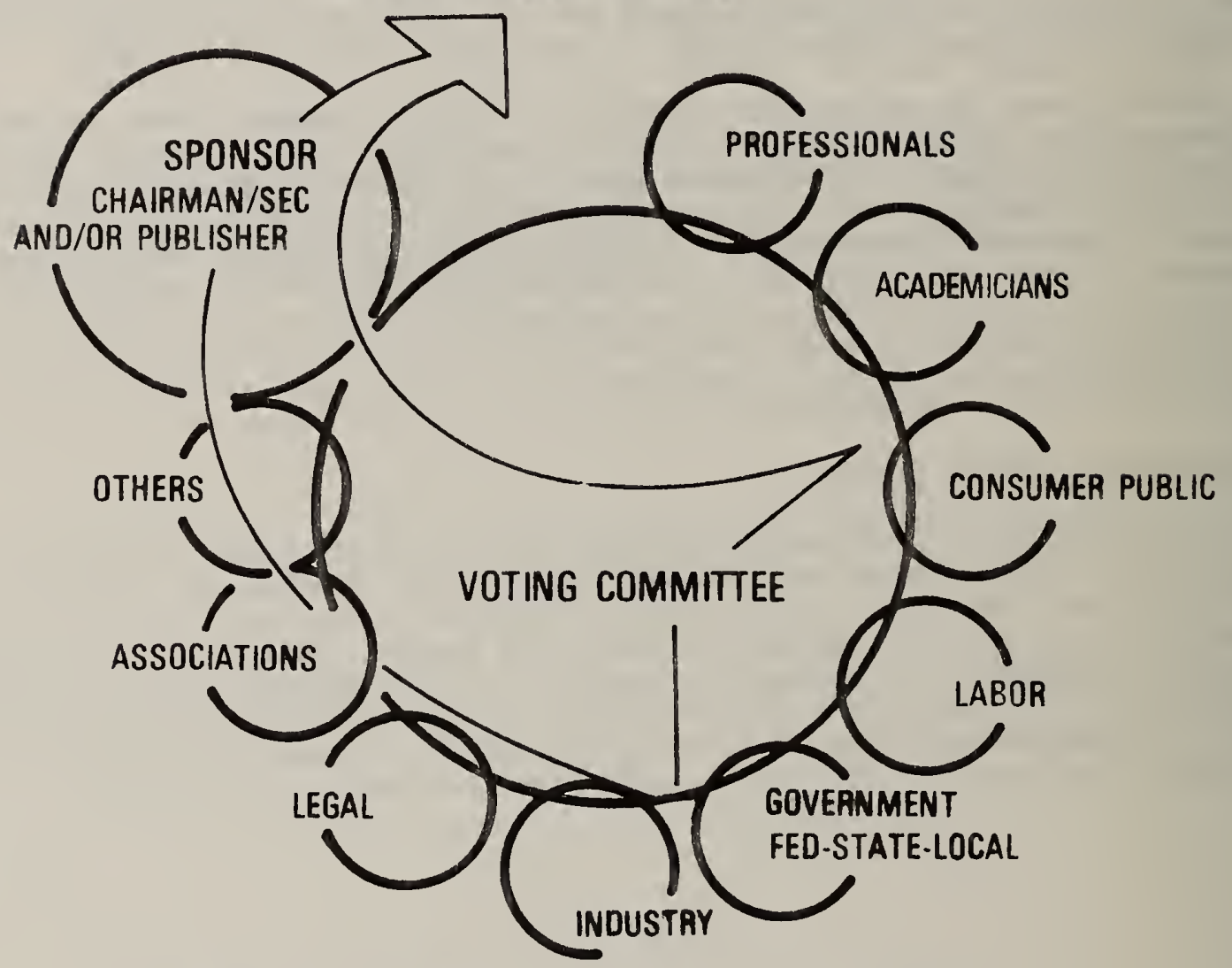

ALL NEGATIVE VOTES MUST BE SUBSTANTIATED \& RESOLVED

Figure 1 - Consensus Standard Development Frocess 


\section{BUILDING REGULATORY PROCESS}

A building code is a legal document which sets forth requirements to protect the public health, safety and general welfare as they relate to the construction and occupancy of buildings and structures. The building code development process in the United States is quite complex. Building codes are normally enacted into law by local governments exercising the police power of the State delegated to them for this purpose. One consequence of this is a considerable diversity of substantive provisions among the thousands of locally-enacted codes. This is true even though three-quarters of locally-enacted codes are based on one of the four model codes. Possible reasons for this diversity are:

o local government frequently alters provisions of the model codes;

- local codes are infrequently updated;

- the model codes are not uniform; and

o some municipalities write their own codes.

\section{A. Mode1 Building Code Organizations}

Except for some of the largest cities, drafting of building codes in the United States is accomplished by the model code associations and allied groups. The first model building code was published in 1905 by the National Board of Fire Underwriters (now the American Insurance Association - AInA) to guide municipalities concerned with reducing the fire hazard in and about buildings. This is now known as the National Building Code [12] which is drafted by engineers of AInA with assistance from many sources.

The other three model code organizations are regionally located and have membership controlled by local government code enforcement officials:

BOCA - Building Officials and Code Administrators International, Inc. (Basic Building Code);

ICBO - International Conference of Building Officials (Uniform Building Code); and SBCC - Southern Building Code Congress International Inc. (Standard Building Code).

The first model code prepared by building officials was the Uniform Building Code [13] developed in 1927 by the Pacific Coast Building Officials (now ICBO). This code is currently used extensively on the West Coast and in the Central Midwest. The Southern Building Code Congress International, Inc., recognizing the unique problems affecting construction in the South, prepared the Standard Bullding Code [14] in 1945. This is the dominant building code in the Southern States. The Basic Building Code [5] was published in 1950 by the Building Officials and Code Administrators International, Inc. and is extensively used in the Upper Midwest, New England and the Middle Atlantic States.

BOCA, ICBO and SBCC consider annual code revisions and publish completely new code editions every three years. Generally, this allows the model codes to be up to date and permits the use of most new materials and new techniques in building construction. Two other important functions provided by these model code associations are those of plan review and product approvals. Product approval allows a manufacturer to get a single approval which can generally apply in all locations where the model code is used.

In addition to building codes, the Model Building Code Organizations also prepare and publish special documents which are designed to be companion documents to their respective building codes and cover the specific requirements for mechanical and plumbing systems, as well as fire prevention. AInA has published a Fire Prevention Code [15] as a companion to the National Builiding Code. BOCA has sponsored a Mechancial Code [16], a Plumbing Code [17], and a Fire Prevention Code [18]. SBCC has issued Mechanica1 [19], Plumbing [20] and Fire [21] Codes. ICBO has jointly sponsored a Uniform Fire Code [22] with the Western Fire Chiefs Association and a Uniform Mechanical Code [23] with International Association of Plumbing and Mechanical Officials (IAPMO). 
In addition to the model building code groups, there are other organizations concerned with building code development. As noted above IAPMO jointly sponsors the Uniform Mechanical Code with ICBO. In addition, IAPMO also prepares and publishes the Uniform Plumbing Code [24]. The National Fire Protection Agency (NFPA) publishes the National Electric Code [25]. The addresses of these organizations, along with the model building code groups are listed in Appendix B.

\section{AMCBO - American Major City Building officials}

The thirty largest cities in this country contain approximately one third of the U.S. population. AMCBO is an organization established as a forum for the major cities involved with the enforcement of building codes.

BCMC - Board for the Coordination of the Model Codes

This organization is a function of CABO and addresses specific model code problem areas. Two recent activities of this organization are the adaptation of ASHRAE 90-75 for uniform inclusion in model codes and the development of uniform egress requirements.

CABO - Council of American Building Officials

CABO was formed in 1971 by SBCC, ICBO and BOCA to work toward uniformity in building codes. CABO provides coordination between the three model code organizations.

IAPMO - International Association of Plumbing and Mechanical officials

IAPMO was established in 1926 by and for inspection officials for cities, counties and states with the goal of bringing about unfformity in plumbing codes and interpretation of the various sections of the codes. IAPMO promulgates and sponsors the Uniform Plumbing Code. In September 1976, IAPMO officially adopted and published their Uniform Solar Energy Code.

MCSC - Model Code Standardization Council

MCSC was formed in 1949 and attempts to obtain uniformity in the model codes. It addresses four major areas (listed below) and includes a broad representation of organizations involved in the development of codes and standards or in enforcement.

o definition

o format

o occupancy classifications

o types of construction

NACA - National Academy of Code Administrators

NACA was established in 1970 for the purpose of developing regulatory code administration as a recognized profession in the United States.

NCSBCS - National Conference of States on Building Codes and Standards, Inc.

NCSBCS was established in 1967 with the goal of achieving a reasonable national uniformity in the regulation of buildings and the acceptance of industrialized buildings across state lines.

NFPA - National Fire Protection Association

NFPA which was organized in 1896 is a nonprofit, technical and educational organization to promote the science and improve the methods of fire protection. NFPA develops codes, standards, and recommended practices to serve as guides to engineered protection for reducing loss of life and property by fire. In addition they educate the public in fire prevention to reduce man-caused fires. 
NRB, appointed by the Board of Directors of CABO, developed and made available to the building public in January 1975, a uniform research recommendation program which is accepted by the members of all three model code organizations. An organization that makes an application to NRB for approval of a product or system has the review of all three technical departments with one national report issued which is used as the criteria for acceptance by buildings officials nationwide.

\section{Building Codes at State Leve1}

The delegation by States of their code-enactment authority to local governments has never been complete. Within the past several years, many states have assumed more active roles in writing, promulgating and enforcing building codes. A growing number of States have withdrawn virtually all authority to enact building codes from their municipalities. There are now 23 States with some type of statewide building code authority which includes approximately half the nation's population [26]. These states are Alaska, New York, Massachusetts, Rhode Island, Connecticut, New Jersey, Maryland, Virginia, North Carolina, Georgia, Florida, Ohio, Indiana, Michigan, Wisconsin, Iowa, Minnesota, New Mexico, Idaho, Montana, Oregon, California, and Washington. Most of these codes are mandatory statewide, but in several states their adoption by localities is voluntary. The nature of the codes also vary since they may include minimum requirements only or may include both maximum and minimum requirements. When a statewide minimum code is provided, the locality is free to adopt stricter requirements; however, if of the minimum/maximum type, the locality must secure State approval of its proposed change on the basis of some unusual condition or special need.

\section{Local Building Code Enforcement}

Statewide code enforcement is usually delegated to the local authority with some supervision, training and assistance from the state. Within single municipalities, the authority to enforce codes may be fragmented among different departments without coordinated supervision. These considerations cause a considerable variation among localities in the interpretation of similar code requirements. 


\section{SOLAR STANDARDS DEVELOPMENT}

The development of standards for solar applications frequently requires interactions between several organizations. Broad-based specifications and standards incorporating a number of materials and components will of ten involve several different areas of expertise; i.e., professions. While some standards are developed by the Federal government and are mandatory in nature, others are developed by voluntary standards organizations, professional organizations or trade or industry associations to meet specific needs. An illustration of the types of interactions that will most likely be involved in the development of solar standards is provided in figure 2.

A. Federal Government - Current Federal government activities are primarily concerned with the refinement of the interim performance criteria intended for use in the various phases of the residential and commercial demonstration programs as well as the refinement of the Intermediate MPS Standards. Over the course of the demonstration programs provided for by PL 93-409, it is expected that these documents will evolve into a document containing definitive performance criteria that can be used as the technical basis for the development of provisions that can be incorporated into model or local building codes or both, as well as in Federal specifications. The basic flow for the development of these standards is shown in figure 3. Although these standards are being prepared under the auspices of the Federal government, their development is dependent upon the availability of standard methods of test, specifications and recommended practices that can be incorporated into them.

1. Intermediate Minimum Property Standards - Standards for solar domestic hot water and space heating systems have been developed as a supplement to the existing FHA Minimum Property Standards. These standards, "Intermediate Minimum Property Standards for Solar Heating and Domestic Hot Water Systems," [27] were developed by NBS for the Department of Housing and Urban Development (HUD). They are intended to serve as a supplement to the basic HUD MPS for use as the basis for mortgage insurance acceptance of systems or components by HUD/FHA. These standards are based on the current state-of-the-art and establish requirements, evaluation procedures, and good engineering practices for solar hot water and heating systems which are intended to result in performance comparable to conventional equipment.

NBS has also developed the "Intermediate Standards for Solar Domestic Hot Water Systems," [28] which have been used for a HUD Solar Hot Water Initiative Program. This document is based on the previously noted standards. The HUD/State Hot Water Initiative Program is a program providing financial assistance to homeowners to install solar domestic hot water systems. The program has been offered in the states of New Hampshire, Vermont, Massachusetts, Rhode Island, Connecticut, New Jersey, Pennsylvania, Delaware, Maryland, Florida, and 13 counties in New York.

2. Interim Performance Criteria - As required by PL 93-409, "Interim Performance Criteria for Solar Heating and Cooling Systems and Dwellings" [29] were prepared by NBS for use by HUD in the residential demonstration program. Shortly thereafter, the National Aeronautics and Space Administration (NASA) developed interim performance criteria for commercial solar heating and cooling systems and facilities [30] for use by the Energy Research and Development Administration (ERDA) in the commercial demonstration program. The NASA document has since been revised by NBS as the "Interim Performance Criteria for Solar Heating and Cooling Systems in Commercial Buildings" [31]. Further revisions will take place on an "as needed" basis when experience gained during the demonstration program makes them meaningful.

The intermediate standards are based on current state-of-the-art technology and are somewhat restrictive because of the prescriptive nature of many of the provisions contained therein. In contrast, the performance based interim criteria do not hinder the use of innovative designs. 


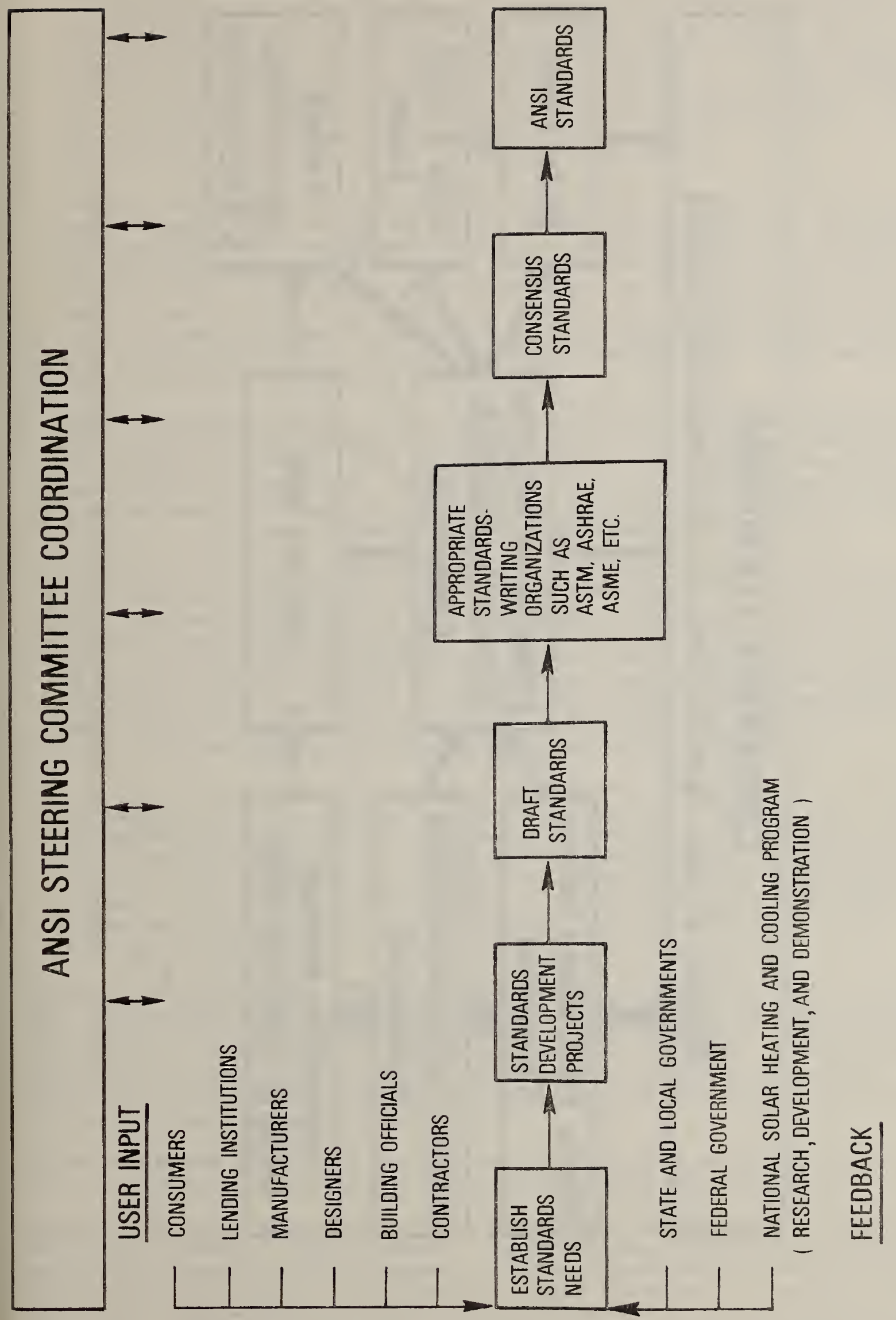




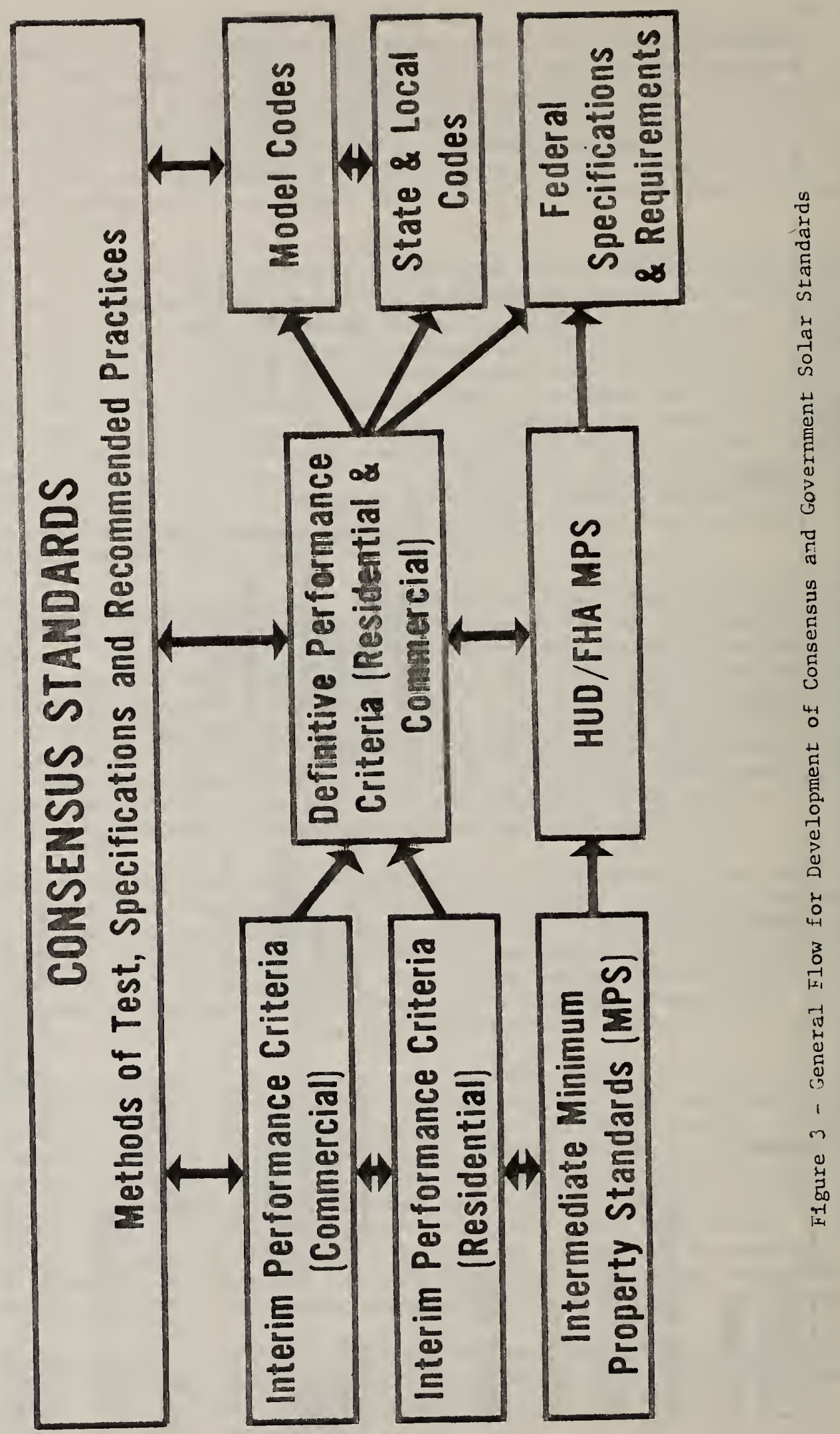


3. Definitive Performance Criteria - As stated in the introduction to this plan, PL 93-409 also requires as soon as feasible and utilizing data available from the residential demonstration program for HUD, utilizing the services of NBS, to determine and publish: (1) definitive performance criteria for solar heating and combined solar heating and cooling components and systems to be used in residential dwellings; and (2) definitive performance criteria (relating to suitability for solar heating and combined solar heating and cooling) for such dwellings. Similar responsibilities for commercial applications have been assigned to NBS by ERDA (now DoE).

Whereas the interim performance criteria are primarily intended for use in procurement during the solar heating and cooling demonstration program, the definitive performance criteria are intended to insure the safety and functionality of solar heating and cooling equipment intended for use by the general public as well as the Federal sector. As was stated previously, it is hoped that they will serve as the basis for model state and local building codes as well as Federal specifications. It is also desirable that the defintive criteria serve as the basis for the development of nationally accepted voluntary consensus standards that can be used for the evaluation and certification of solar equipment.

4. Mode1 Solar Code Provisions - As a result of a DoE sponsored study undertaken by NBS, a recommendation was made that a single regulatory standard on Model Solar Code be developed by the end of 1978 and be processed as a consensus document for ultimate adoption by State, local and other regulatory jurisdictions. The regulatory document would be generated through the efforts of the professional societies, the solar industry, the consumer and with State, local and Federal participation.

The initial NBS study was a six-month effort utilizing the services of the model code organizations (CABO, BOCA, ICBO, SBCC), a professional society (ASHRAE), NCSBCS, NIBS, the American Institute of Architects Research Corporation (AIA/RC), and the Planning Research Corporation (PRC). In addition to the Model Solar Code recommendation, the study group identified general research needs, and issues and concerns to be considered in developing the Model Solar Code, and outlined a general plan for development and implementation. Furthermore, the model code organizations reviewed their respective codes and proposed interim code changes that would facilitate the use of solar while the single standard Model Code was being developed.

A consolidated report has been prepared by NIBS which sunmarizes the activities and recommendations of the study and has been distributed to a balanced cross-section of the building community and public interests for comment. After receipt of comments by the reviewing organization, a Final Consolidated Report will be prepared as guidance and direction for future activities in the preparation of a regulatory standard on Model Solar Code Provisions. It is anticipated that this effort will discourage the proliferation of numerous non-uniform code provisions by State and local jurisdictions.

State and Loca1 Government - NBS has recently completed a state legislative survey of state bills enacted in 1976 and subsequent state actions relative to solar applications [32]. As of January 1978, five states (Minnesota [33], Oregon [34], Virginia [35], California [36], and Florida [37]) were developing solar standards. North Carolina, Washington, and Connecticut rely on Federal government or association standards. Other states have passed laws relating to solar incentives which will also require standards by which to judge acceptable systems.

Little information is currently avallable as to the status of solar standards or technical regulations which may have been adopted by local jurisdictions.

Standards-Writing and Code Organizations - ASHRAE, ASTM and ASME have committees which are actively working on solar standards. ASHRAE Committees 93 and 94 developed and published test procedures for determining the thermal performance of solar collectors and thermal storage devices, respectively, as ASHRAE Standards 93-77 and 94-77 [38 and 39]. These test procedures are based on draft standards previously developed by NBS [40 and 41]. ASHRAE Committees 95 and 96, respectively, are currently developing test procedures for determining the thermal performance of domestic hot water and swimming pool systems. 
ASTM Subcommittee E21.10, "Solar Heating and Cooling Applications," was formed in November of 1975 to expedite the development of standards needed to implement the "National Solar Heating and Cooling Demonstration Act of 1974." Task groups of this subcomittee are concerned with the safety, durability/reliability, and thermal performance of materials, subsystems, and systems used for various solar applications. It is anticipated that the subcommittee will become a full ASTM Committee in June 1978 with the title Solar Energy Conversion.

The ASME Solar Energy Standards Development Committee was formed in February 1977 to prepare standards related to the mechanical safety and function of solar collectors, thermal storage subsystems, energy transport subsystems, heat exchangers, pumps, filters, and valves.

In the development of the performance version of the National Plumbing Code, the ANSI A40 Committee intends to consider the inclusion of a chapter on solar systems.

The International Association of Plumbing and Mechanical Officials (IAPMO) prepared and published a model solar code in September 1976 entitled the "Uniform Solar Energy Code" [42]. The document is intended to provide a safe and functional solar energy system with a minimum of regulations. The provisions apply to the erection, installation, alteration, addition, repair, relocation, replacement, maintenance or use of any solar system.

In addition, the Sheet Metal and Air-Conditioner Contractor's National Association, Inc. (SMACNA), with financial support from HUD, developed and published in February 1977 a document entitled "Heating and Air-Conditioning Systems Installation Standards for One and Two Family Dwellings and Multifamily Housing Including Solar" [.43]. This document contains modifications and additions to the established SMACNA Standards for the inclusion of solar energized space heating and cooling and solar heating of domestic hot water. As of mid-January 1978, 17 local jurisdictions have adopted this standard.

D. Coordination of Activities - Since solar standards are needed at several levels; 1.e., systems, subsystems, components and functional materials, and because they involve many different areas of expertise; i.e., thermal design, mechanical design, fire safety, etc., their development will require the involvement and coordination of many different standards-generating organizations. In addition, because of the various activities described above which are now underway, coordination and lines of communication between organizations are very important. This coordination effort would serve the purpose of preventing duplication of efforts as well as ensuring that no gaps are left in the development of needed standards.

In January 1976, based on NBS' recommendations, ANSI established a Steering Committee on Solar Energy Standards Development. The scope and purpose of this committee is as follows:

\footnotetext{
"Without engaging in standards-writing activities, identify needs and formulate specific tasks leading to the development of national consensus standards for utilization of solar energy for heating and cooling. Assign standards development projects to competent standards-writing organizations, and maintain a continuous overview of their activities in order to assure an orderly and effective process which will avoid duplication of effort and conflicting standards."
}

In areas where high priority needed standards have already been identified on the basis of prior experience, it is desirable that the development of these standards be started as soon as possible. Preliminary draft standards could be developed by organizations in either the public or private sectors possessing the necessary expertise. However, it is important to avold potential conflicts of interest that could arise in the development of such drafts. 
Currently, 22 organizations are represented on the ANSI Solar Energy Steering Committee. They are Air Conditioning and Refrigeration Institute, American Gas Association, American Institute of Architects, Architectural Aluminum Manufacturers Association, American Society of Heating, Refrigerating and Air-Conditioning Engineers, American Society of Mechanical Engineers, American Society for Testing and Materials, Consumer Action Now, Department of Energy, Department of Housing and Urban Development, General Services Administration, Institute of Electrical and Electronics Engineers, International Association of Plumbing and Mechanical Officials, Manufactured Housing Institute, Mechanical Contractor's Association of America, Inc., National Aeronautics and Space Administration, National Association of Home Builders, National Bureau of Standards, National Conference of States on Building Codes and Standards, Sheet Metal and Air-Conditioning Contractor's National Association, Solar Energy Industries Association and Underwriters Laboratories. A membership list of the ANSI Steèring Committee on Solar Energy Standards Development is included in Appendix A.

The original NBS Standards Development Plan (NBSIR 76-1143) was formally endorsed and approved by the ANSI Solar Energy Steering Committee in January 1977. Since then revised drafts of the tables contained in Section VII of this report were reviewed by the ANSI Committee during its meetings held in October 1976 and January, April, July, and October of 1977 plus January 1978. Comments received as a result of these reviews were incorporated in the preparation of the tables in this report which were approved at the ANSI Steering Committee meeting on April 12, 1978. 
The implementation of the definitive solar performance criteria and the accompanying standards for materials, components and systems needed for criteria evaluation will require a comprehensive plan to accomplish nationwide deployment through the existing bullding regulatory system. This is especially critical since the existing system is already burdened with existing comitments.

During the implementation phase of these standards, it will be necessary to provide assistance to the formulators of model codes, building regulators, builders and design professionals. The program outlined below addresses the major areas of assistance which will be required. It should be noted that several of these implementation activities (laboratory accreditation and solar equipment certification) depend on the avallability of standards. Tables addressing various standards are given in Section VII.

\section{Activities}

1. Criteria for Testing and Laboratory Accreditation - The previously referenced paragraph from Section 8 of PL 93-409 concerning the certification of solar heating and cooling components and systems will require the development of an institutional mechanism for the accreditation of laboratories which can provide such certification. Specifically, criteria should be developed to evaluate and accredit laboratories to perform component testing and compliance assurance functions required by regulatory authorities.

There are both short term and long term considerations to establishing a laboratory accreditation program. The Solar Demonstration Programs (Residential and Commercial) will require the identification of acceptable laboratories for evaluating solar equipment in a short time frame. This can be accomplished by the Federal agencies (HUD, DoE, DoC, etc.) in cooperation with the private sector. In order to meet this need, NBS contracted with the ARI Foundation, Inc. (ARIF), a subsidiary of the Air-Conditioning and Refrigeration Institute (ARI), in 1977 to investigate and identify laboratories that were qualified to test solar collectors in accordance with the ASHRAE Standard 93-77. In conducting this effort, ARIF developed criteria for evaluating the qualifications of testing laboratories. NBS is currently preparing a summary report of the ARIF investigation. To help meet longer term needs, the Solar Energy Research and Education Foundation (SEREF), a subsidiary of the Solar Energy Industries Association, is currently working under a Federal Energy Administration (FEA) (now DoE) contract to design a program which will provide for the physical testing, rating, certification, and labeling of solar collectors. As part of this effort, SEREF is developing procedures for accreditin laboratories for the testing of solar equipment.

On February 1, 1978, the California Energy Resources Conservation and Development Conmissio (ERCDC) adopted preliminary regulations and guidelines establishing standards and procedures [44] to accredit testing laboratories for solar equipment. This commission is now officially accepting applications from all laboratories (worldwide) for accreditation to test solar equipment. Currently, flat plate liquid solar collectors are the only item for which laboratories may be accredited to test. However, other solar components will be added to the list later.

In the long term, the viability of a solar industry will require the development of a permanent laboratory accreditation mechanism. The National Voluntary Laboratory Accreditation Program (NVLAP) represents a logical procedure to follow. As stated in Part 7 - Procedures, as published in the Federal Register, Volume 41, Number 38, February 25, 1976, "The goal of this program is to provide, in cooperation with the private sector, a national voluntary system to examine upon request the professional and technical competence of private and public testing laboratories that serve regulatory and non-regulatory product and certification needs. The program is also intended to accredit those laboratories that meet the qualifications which will be established under these procedures." As noted in the National Program for Solar Heating and Cooling (ERDA 76-6), it is the intent of the Federal government to use NVLAP for the accreditation of laboratories for the testing of solar components, subsystens and systems. DoE, in cooperation with HUD and NBS, is currently initiating action for the accreditation of laboratories to test solar collectors through NVLAP. 
The accreditation of laboratories through NVLAP requires the development of specific criteria or standards to accredit testing laboratories such as organization, staff, physical plant, operational processes, control procedures, quality assurance, and professional and ethical business practices. Paragraph 7.7 (b) of the February 25, 1976, Federal Register notice states "specific criteria... will be based upon criteria found in existing standards where such existing criteria are deemed appropriate. Where appropriate existing criteria cannot be found, the Criteria Committee will, at the request of the Secretary, undertake to develop and recommend to him such appropriate general and specific criteria..."

Certification of Solar Equipment - Standards must be available to which a solar energy system, subsystem, or component can be evaluated by an accredited testing laboratory. These standards could include requirements for testing and rating, definitions and classifications, specifications, literature and advertising requirements, performance requirements, and safety requirements.

Also, it will be necessary to develop model evaluation procedures and documents which will allow an efficient, and unfform evaluation of solar equipment by accredited testing laboratories. These could include:

a. test data and information to be submitted to accredited laboratories by producers;

b. evaluation procedures, techniques and guidelines to be used by accredited laboratories;

c. model formats for approval reports to be issued by accredited laboratories;

d. inspection procedures and techniques to assure compliance to the standards; and

e. data and information to be submitted to local enforcement agencies pertaining to installation and/or occupancy.

Currently, there are activities in process chat deal with the certification of solar equipment by state agencies in Florida and California and organizations such as ARIF, ARI and SEREF. The 1976 Florida Legislature enacted the Solar Energy Standards Act of 1976, now Section 377.705, of the Florida Statutes. This 1aw, effective October 1, 1976, directed the Florida Solar Energy Center (FSEC) to develop standards for solar energy equipment sold or manufactured in the state, establish criteria for determining the performance of solar energy equipment and maintain a testing facility for evaluating solar energy equipment performance. As a result of this directive, FSEC prepared a document, FSEC 77-6, "Operation of the Collector Certification Program," [45] which presents details of the testing and standards program whereby solar collectors may be rated for performance, examined for compliance to minimum standards and approved to bear a label of certification from FSEC.

As indicated previously, the Calffornia ERCDC adopted regulations and guidelines establishing standards and procedures to accredit testing laboratories for solar equipment. The laboratory accreditation, however, will authorize testing but not certification of solar components. Certification of solar components for California will be issued by ERCDC including a certification label. One of the requirements for certification will be successful testing by a laboratory accredited by ERCDC. This Commission has recently conducted public hearings on their preliminary draft of the proposed certification criteria to be used in the California Testing and Inspection Program for Solar Equipment [46].

In addition to the identification of laboratories qualified to test solar collectors under their NBS contract, ARIF also developed draft documentation for a solar collector certification program which included a solar collector rating standard and a certification program operational manual [47]. In January 1978, ARI announced the initiation of an industry voluntary certification program for thermal performance of solar collectors in accordance with their operational manual and their Standard 910-77, "Rating Standard for Solar Collectors." They have been soliciting collector manufacturers regarding their interest in participating in the ARI program.

As mentioned previously, SEREF is also currently working on a program for the rating, certification, and labeling of solar collectors. 
3. Legislative, Administrative and Advisory Services to the States - It is necessary to provide the professional and administrative services that will be required by the building regulatory community in the development of legislative and regulatory requirements as a result of solar standards implementation. This need is recognized in section 12 of PL 93-409, "study and investigate the effect of building codes...upon the practical use of solar energy" and "determine the extent to which such laws, codes, ordinances, and practices should be changed to permit or facilitate such use." Assistance should be provided to the States for the evaluation of viable alternative approaches among administrative programs, rules and regulations, and administrative procedures necessary for effective implementation.

4. Educational Programs - The introduction of solar standards will impose additional burdens on the building regulatory community in the form of new technology requirements. It will be necessary to provide training for members of this community on the provisions of the standards. Educational programs should also be developed to serve the needs of designers, builders and installation and service contractors.

5. Manuals of Accepted Practice (MAP) - Manuals of accepted practice will assist building regulators, designers and builders by cataloging and illustrating information and designs that will satisfy the provisions of the solar standards. This would ease the impact on the design community of introducing new performance standards by allowing reference to construction designs known to be acceptable to building regulators. While manuals of accepted practice assist in using and complying with standards, they are not standards themselves nor have they been generally developed through a "consensus process." Manuals are generally "living" documents where new designs, systems, procedures, etc. are added as they are shown to comply with a regulatory standard. An example of such a document is the Manual of Accepted Practice for the FHA Minimum Property Standards [48].

6. Incorporation of Solar Standards into Model Bullding Codes - In order to ensure implementation of the solar standards on a national scale, it will be necessary to have them adopted in some form by the model code groups (ICBO, BOCA, SBCC, AInA), and state and local jurisdictions. It is likely that many of the provisions of the standards will not be presented in a manner that will allow them to be adopted as enforceable regulations in the present structure of building codes and standards. A DoE sponsored study to develop interim solar code provisions and to develop a plan for a Model Solar Code is discussed in Section V A.4 of this report.

7. Technical Support for Building Regulatory Community - Questions of a technical nature will arise during the implementation phase of the solar standards. These will include interpretation of provisions and resulting identification of areas where additional research is needed. A mechanism should be developed to provide such interpretations, and to identify needed revisions in the standards, and to support additional technical needs.

8. Feedback of Data from Field - It is important that feedback of experience from the field occur in order that the standards can be revised as necessary, manuals of accepted practic can be expanded to include successful applications, training programs can be improved, etc 


\section{$\underline{\text { Standards Development }}$}

Standards for solar heating and cooling systems, and their various subelements, are needed to establish acceptable minimum requirements for health and safety as well as acceptable minimum levels of technical performance; i.e., thermal performance, durability/ reliability, etc. These standards, which would include standard methods of test, recommended practices and specifications, would be of value to a wide range of users; i.e., designers, manufacturers, installation contractors and purchasers.

An attempt has been made to identify standards which are known to require further development and to assign priorities for their development. These priorities can be further defined on the basis of a comparison of actual with predicted system and subsystem performance, on a study of failures that occur in system operation, on past experience with similar equipment used under either identical or similar operating conditions, and on specific needs that are identified by the user (designers, manufacturers, regulatory agencies, etc.) of such standards.

Standards which have been identified by NBS, working in conjunction with the ANSI Steering Committee, as requiring development are listed in the tables which follow. The tables do not include those available standards which were believed could be used without modification. It is possible that several of the items identified as requiring separate standards in the tables can be combined into one standard; $1 . e .$, a single method of test for both commercial and residential heating and cooling systems. However, it is not possible to ascertain at this time whether or not these standards will be combined.

The tables include the following standards (see page 4 for definitions of standards):

1. Method of Test Standards

I. Functional

II. Durability/Reliability

III. Safety (Electrical, Fire Toxicity, Impact, etc.)

2. Recommended Practice Standards

I. Design and Selection

II. Installation

III. Operation

IV. Maintenance

3. Specification Standards

I. Systems

II. Subsystems

III. Components

IV. Functional Materials
Tables A1-A2

Tables A3-A4

Table A5

Tables B1-B3

Table. B4

Table B5

Table B6

Table C1

Table C2

Table C3

Table C4

Each required standard has been ranked as either: high-1, high-2, high-3, medium, or low in descending order or priority. Where possible, organizations which would probably be responsible for developing the standards are listed along with estimated development schedules. The status of each standard has been categorized using the following key:

1. Required modifications to existent standards being made.

2. Existent standards available but require modification.

3. Final draft standard prepared but requires consensus review and acceptance.

4. Preliminary draft prepared but requires further modification.

5. Preliminary draft requirements under study.

6. Procedures available, but not recognized standards.

7. Consensus standard available. 
B. Standards Implementation

The following tables outline various activities which should be initiated to expedite the implementation of solar standards as discussed in Section VI:

1. Qualification/Accreditation of Laboratories - Table D1

2. Certification Table El

C. Organizations Involved in Development of Listed Standards

The following organizations, listed in alphabetical order, are involved in the standards development activities identified in the Tables Al through E1:

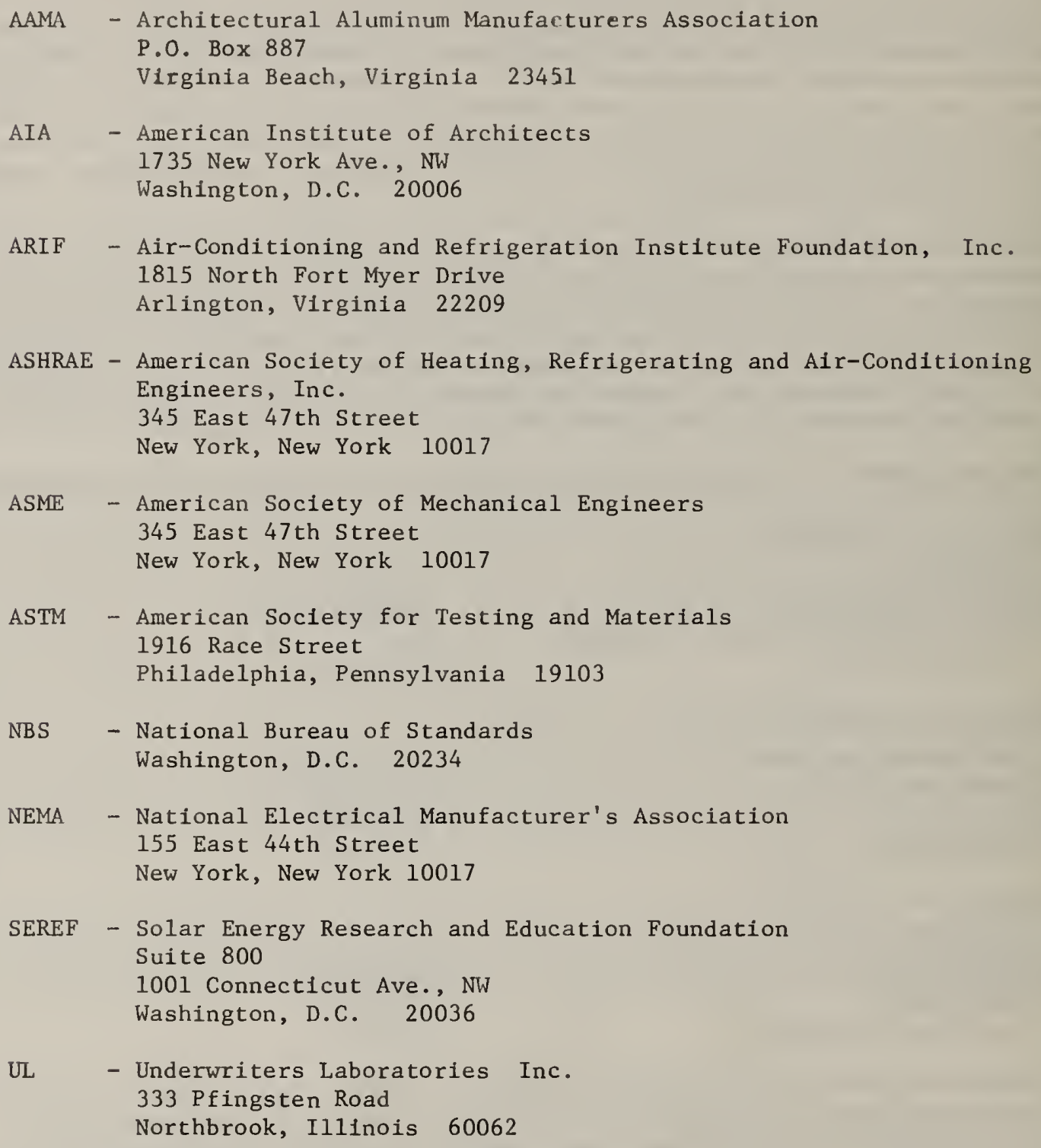

D. Standards Activities Initiated or Completed

Tables F1 to F4 describe the scope of various standards development activities that have been started and identify the organization responsible for each consensus standard development. Table Gl describes the scope of completed standards development. 
Although there is a very definite need for training programs of various types and manuals of accepted practice, the opinion of the ANSI Solar Steering Committee was that there is no requirement for the establishment of rules to measure the quantity, quality, value or extent of training programs or manuals of accepted practice at this time. However, they felt that a listing of available training programs and manuals would be helpful. Accordingly, the following information is provided:

\section{Training}

There are numerous courses being provided by colleges, universities, vocational and technical schools throughout the United States which offer some aspect of solar or solar-related study. The names of the institutions providing these courses may be obtained by writing the National Solar Heating and Cooling Information Center, P.0. Box 1607, Rockville, Maryland 20850 or calling toll free 800-523-2929 (in Pennsylvania, call 800-462-4983). In addition, there are a number of DoE workshops held periodically on various topics, i.e., passive systems, thermal storage, solar collectors, etc. Information on these activities can also be obtained from the National Information Center.

The following list contains names that were known to the National Bureau of Standards at the time of this writing. Since NBS does not evaluate these services, the appearance of names on this list does not indicate endorsement nor does the absence indicate disapproval. Perlodic updates will be made when this report is revised in the future.

1. Correspondence cource in the installation and maintenance of solar heating and cooling equipment--"Fundamentals of Solar Heating"

Home Study Institute

A division of North American Heating and Air Conditioning Wholesalers Association (NHAW)

1661 West Henderson Road

Columbus, $\mathrm{OH} \quad 43220$

(614) $459-2100$

2. Solar Heating and Cooling - Residential and Commerclal Applications

Continuing Engineering Education

George Washington University

Washington, D.C. 20052

(202) 676-6106

3. Solar Energy Seminar Discussions

New York University

School of Continuing Education

Division of Career and Professional Development

326 Shimkin Hall

New York, NY 10003

4. Solar Energy for Buildings, Houses and Pools

Continuing Education in Engineering

University of California at Berkeley

2223 Fulton Street

Berkeley, CA 94720

(415) 642-4151

5. Solar Energy Seminar

New York Management Center

Department 14NR

360 Lexington Avenue

New York, NY 10017 
6. Solar Heating Course

The Center for Cost Effective Solar Systems

Solar Courses

Cambridge School

Georgian Road

Weston, MA 02193

(617) $965-5428$

7. Energy Conservation and Solar Energy Workshops

Arnold and Maria Valdez

Future Power at San Luis

Route 1, Box $3 \mathrm{~A}$

San Luis, CA 81152

8. Solar Technology, A Five-Week Course in Solar Home Design

Colorado Sunworks

P.O. Box 455

Boulder, CO 80302

9. Solar Energy for Domestic Heating and Cooling

New York University

School of Continuing Education

Business and Management Division

360 Lexington Avenue

New York, NY 10017

800-223-7450

10. The Practical Design and Economics of Solar Heating and Cooling Systems Center for Management and Technical Programs

Division of Continuing Education

University of Coloardo

Box 3253

Boulder, CO 80307

(303) 492-8356

11. Solar Energy Source

University of California Extension

Davis, CA 95616

12. Practical Application of Solar Heating and Cooling in Building Construction University of Wisconsin, Extension

Department of Engineering and Applied Science

432 N. Lake Street

Madison, WI 53706

13. Solar Energy Applications

American Institute of Chemical Engineers

Continuing Education Department

345 East 47 th Street

New York, NY 10017

(212) $644-7526$

14. Solar Energy for Home and Buildings

Energy Education Services of Connecticut (EESC)

266 Pearl Street

Hartford, CT 06103 


\section{Manuals for Accepted Practice}

At this writing there is not much to offer in the way of Manuals of Accepted Practice.

It is sincerely hoped that future revisions of this report will include many more entries. The title, source and cost of avallable manuals is listed below.

1. "Heating and Air Conditioning Systems - Installation Standards for One and Two Family Dwellings and Multifamily Housing Including Solar," available from the Sheet Metal and Air Conditioning Contractors' National Association, Inc., 8224 01d Courthouse Road, Tysons Corner, Vienna, Virginfa 22180 ( $\$ 10.00-$ individuals). 


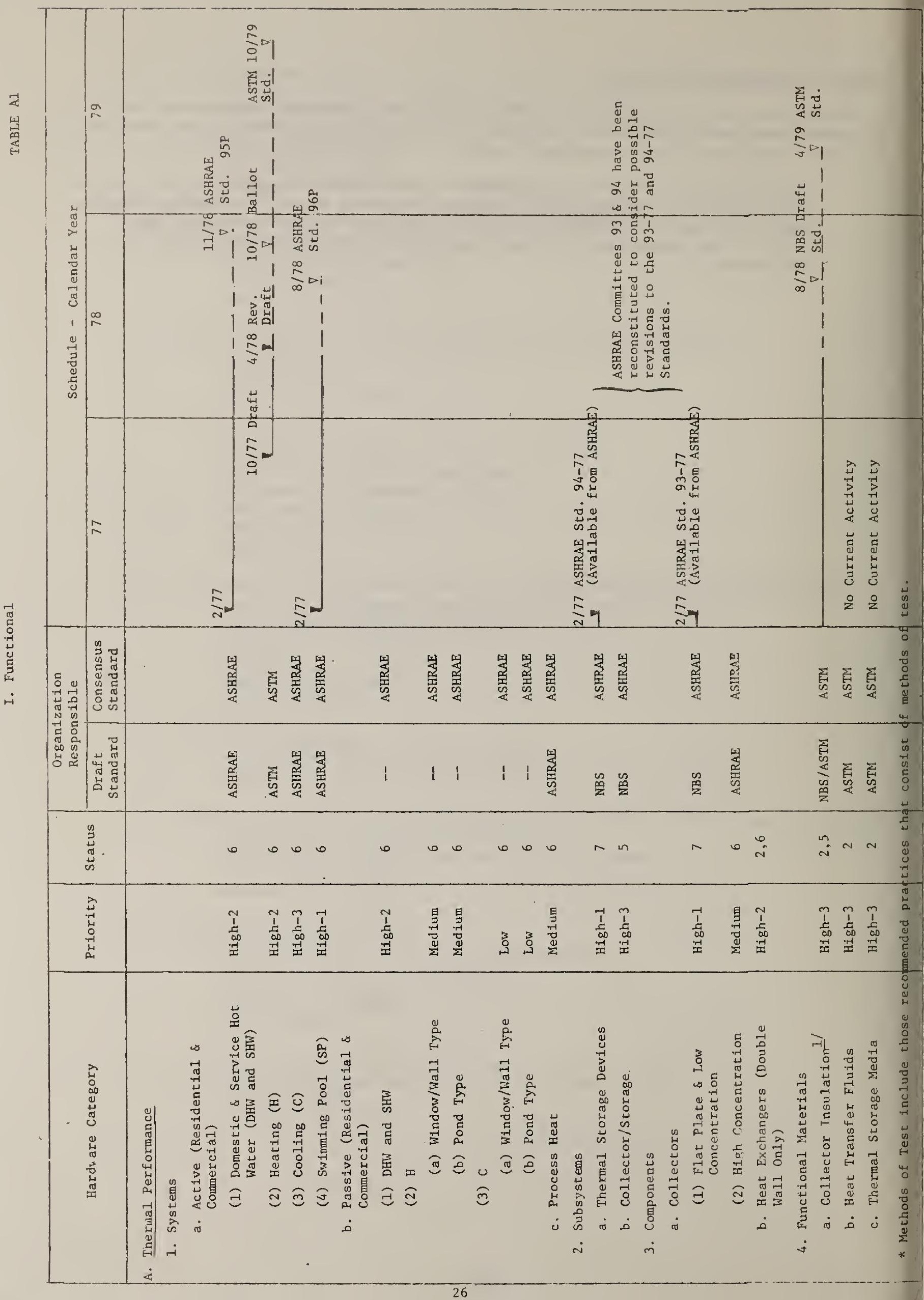




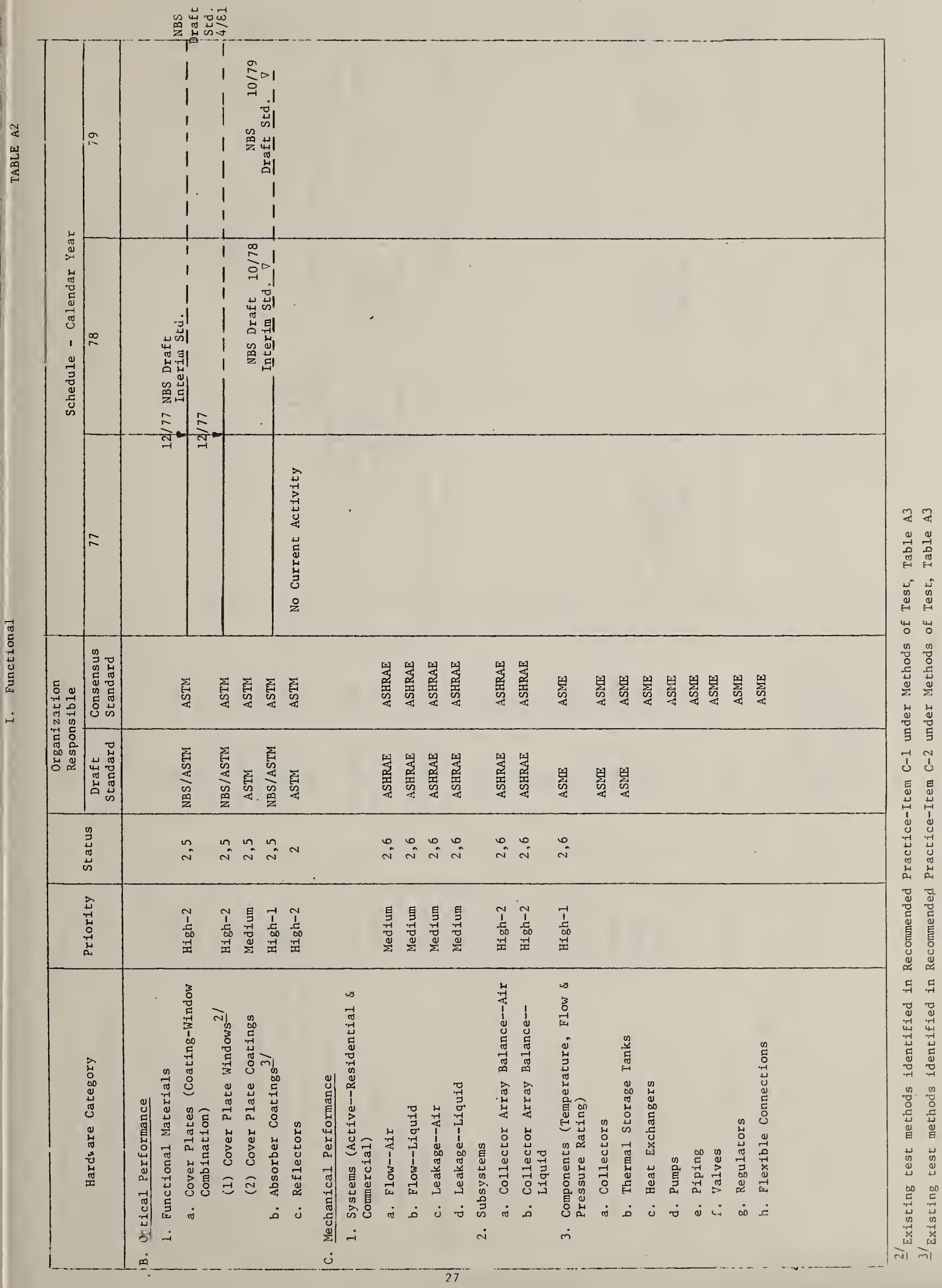




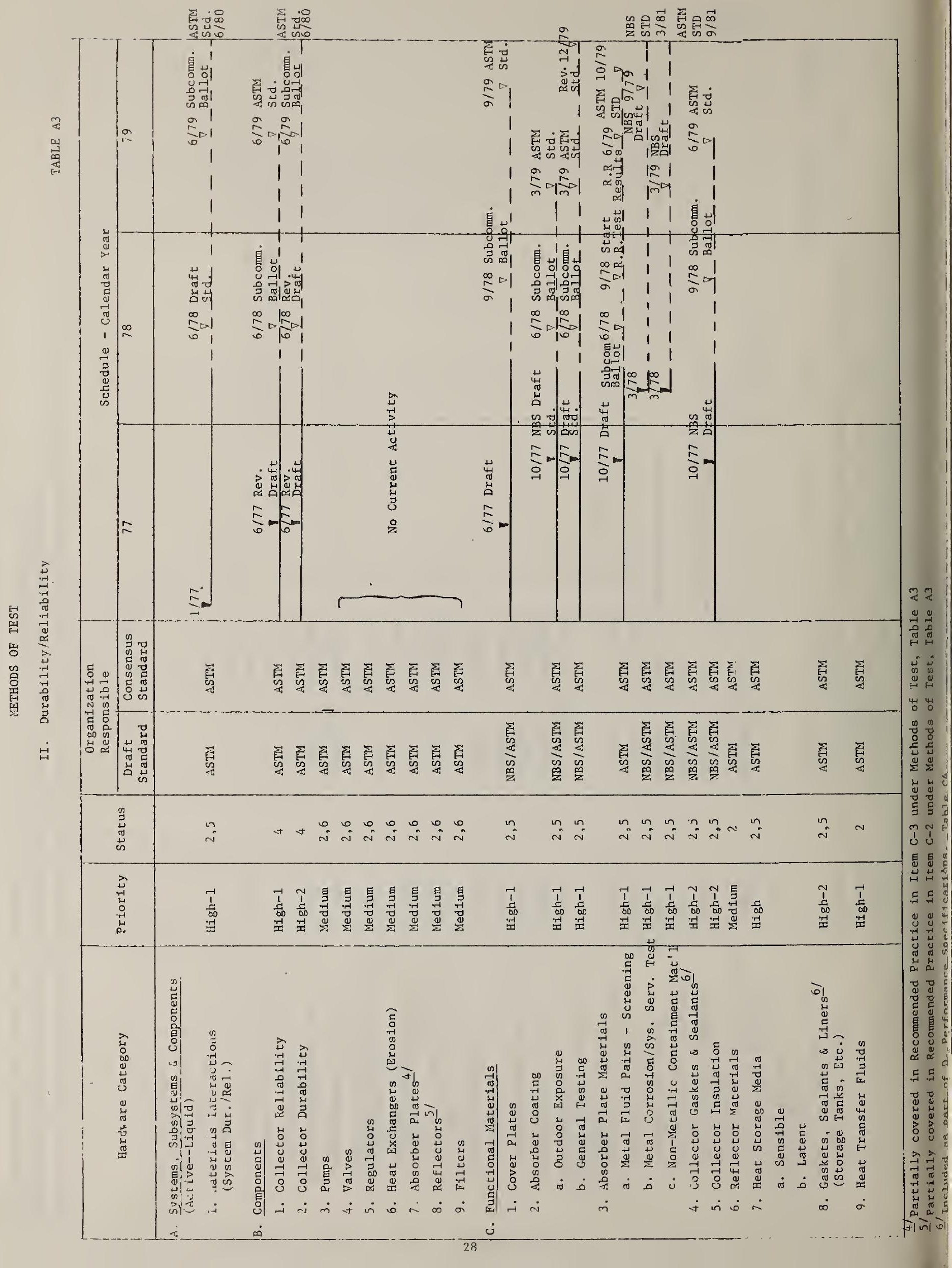




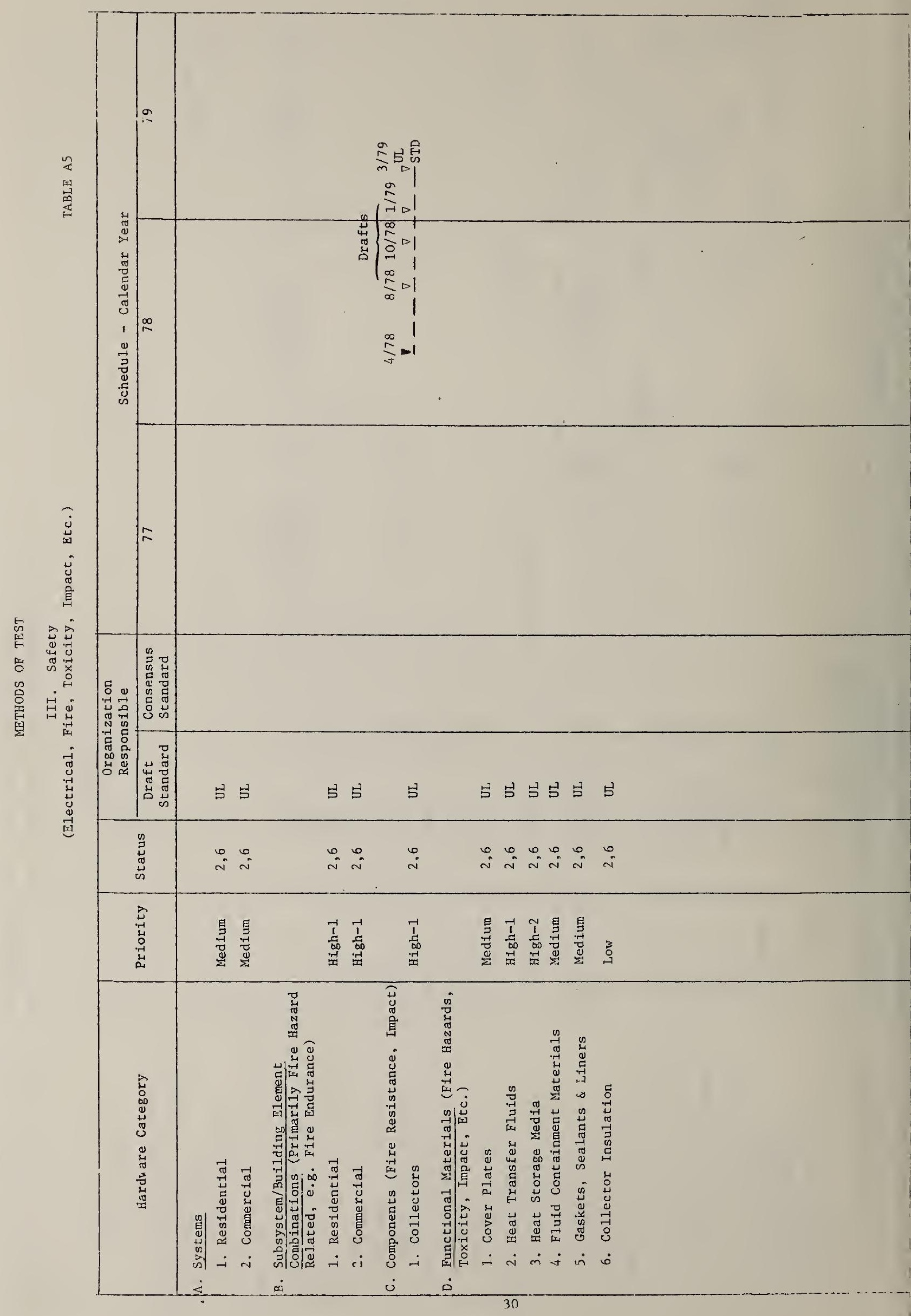




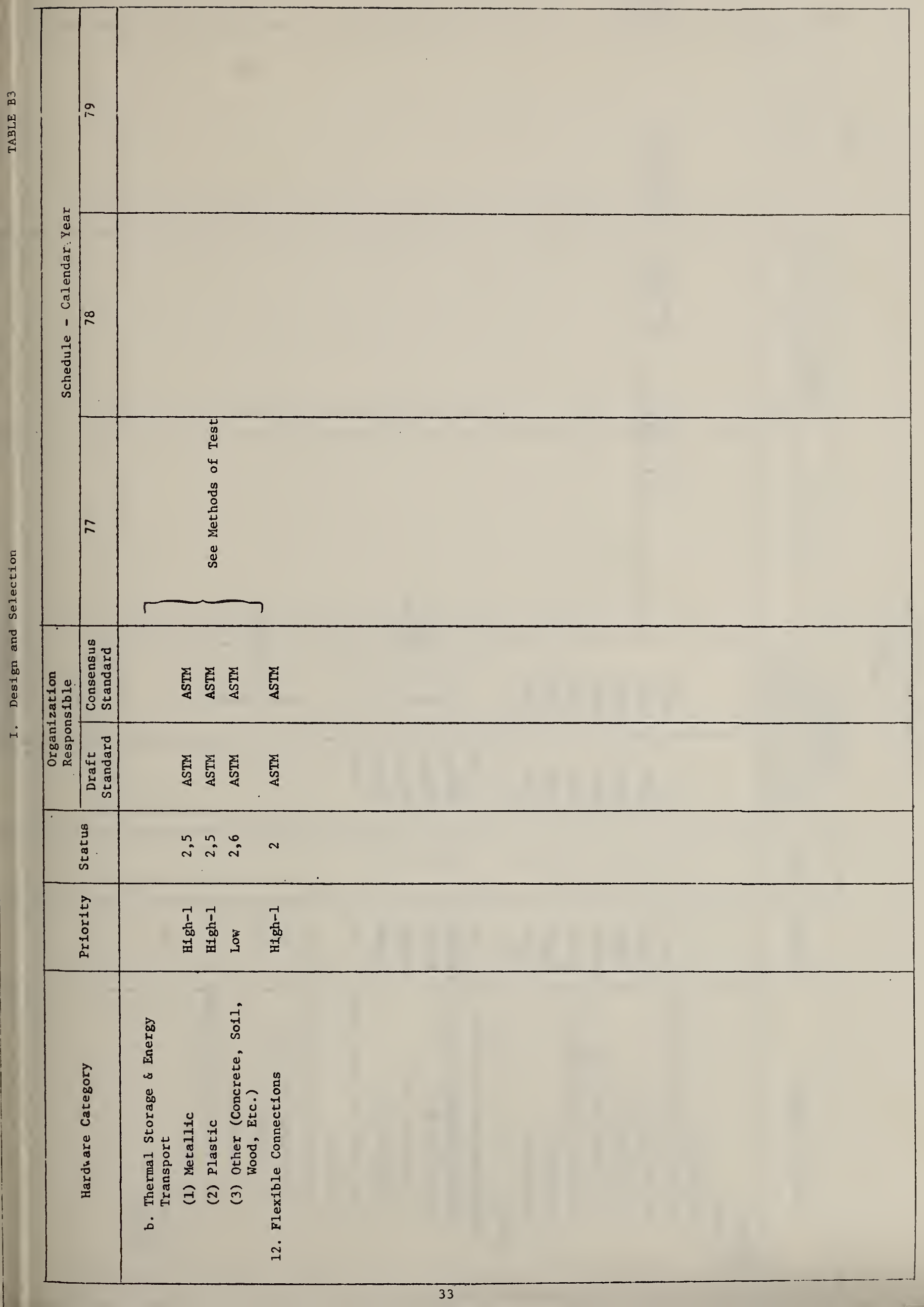




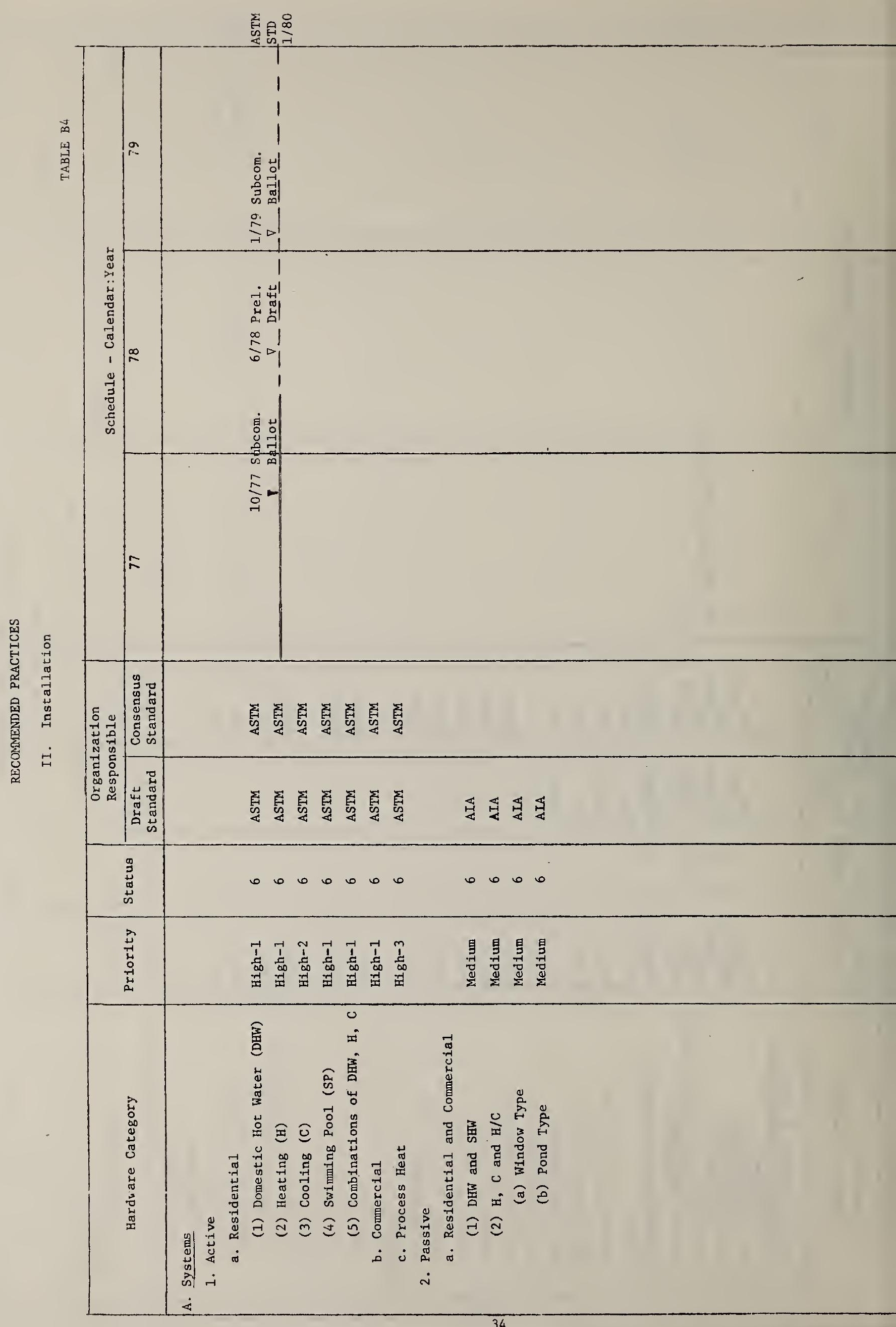




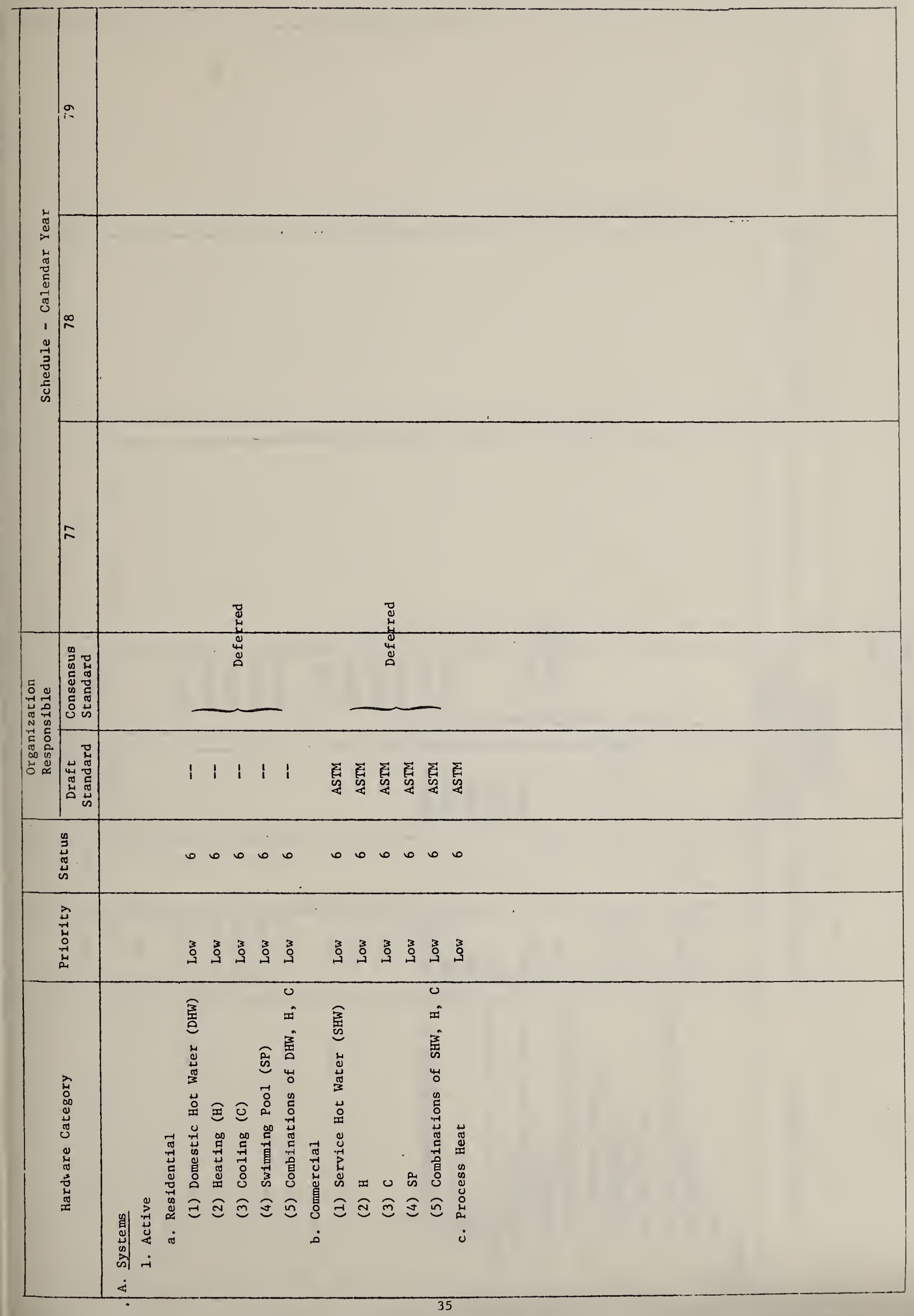




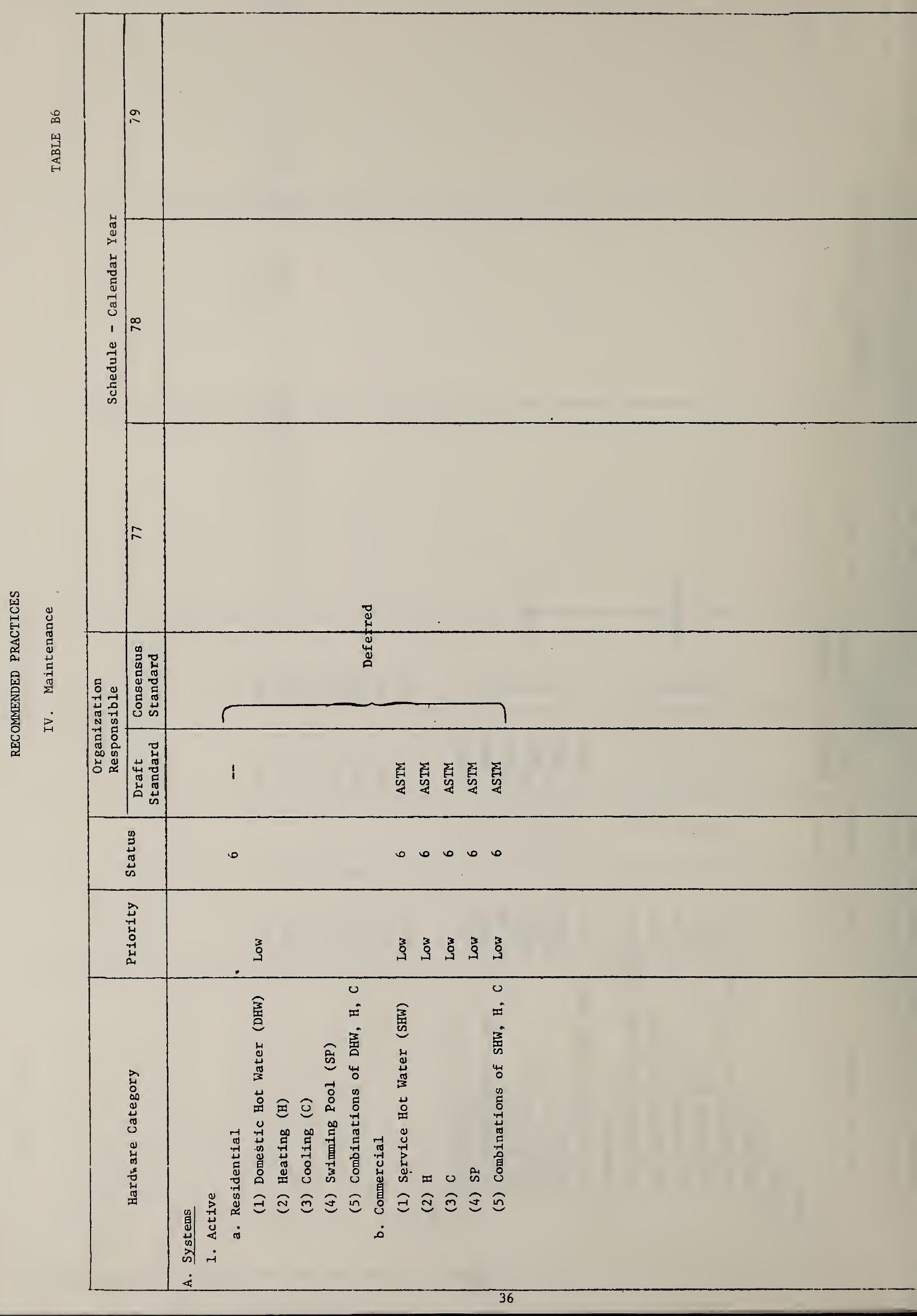




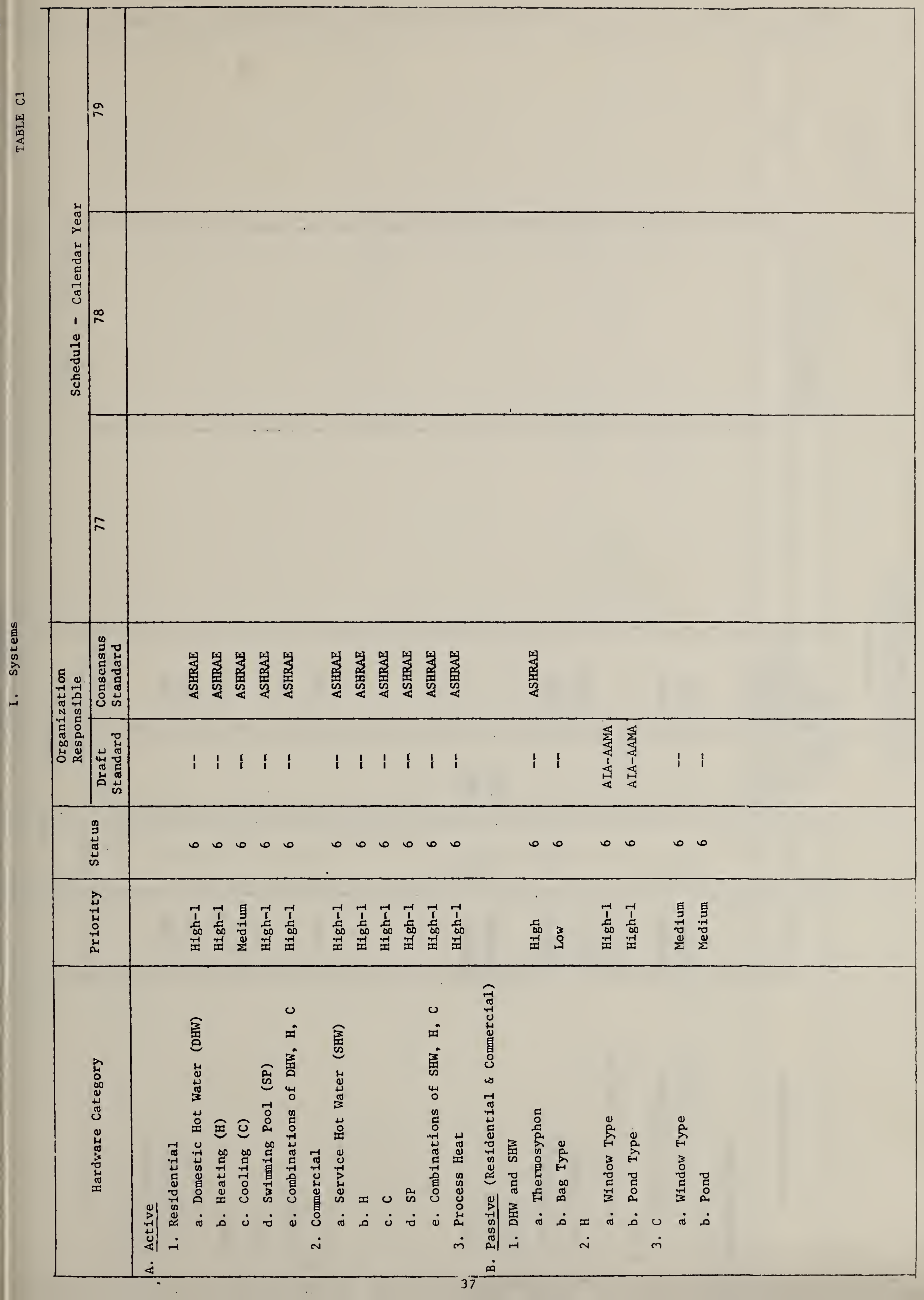




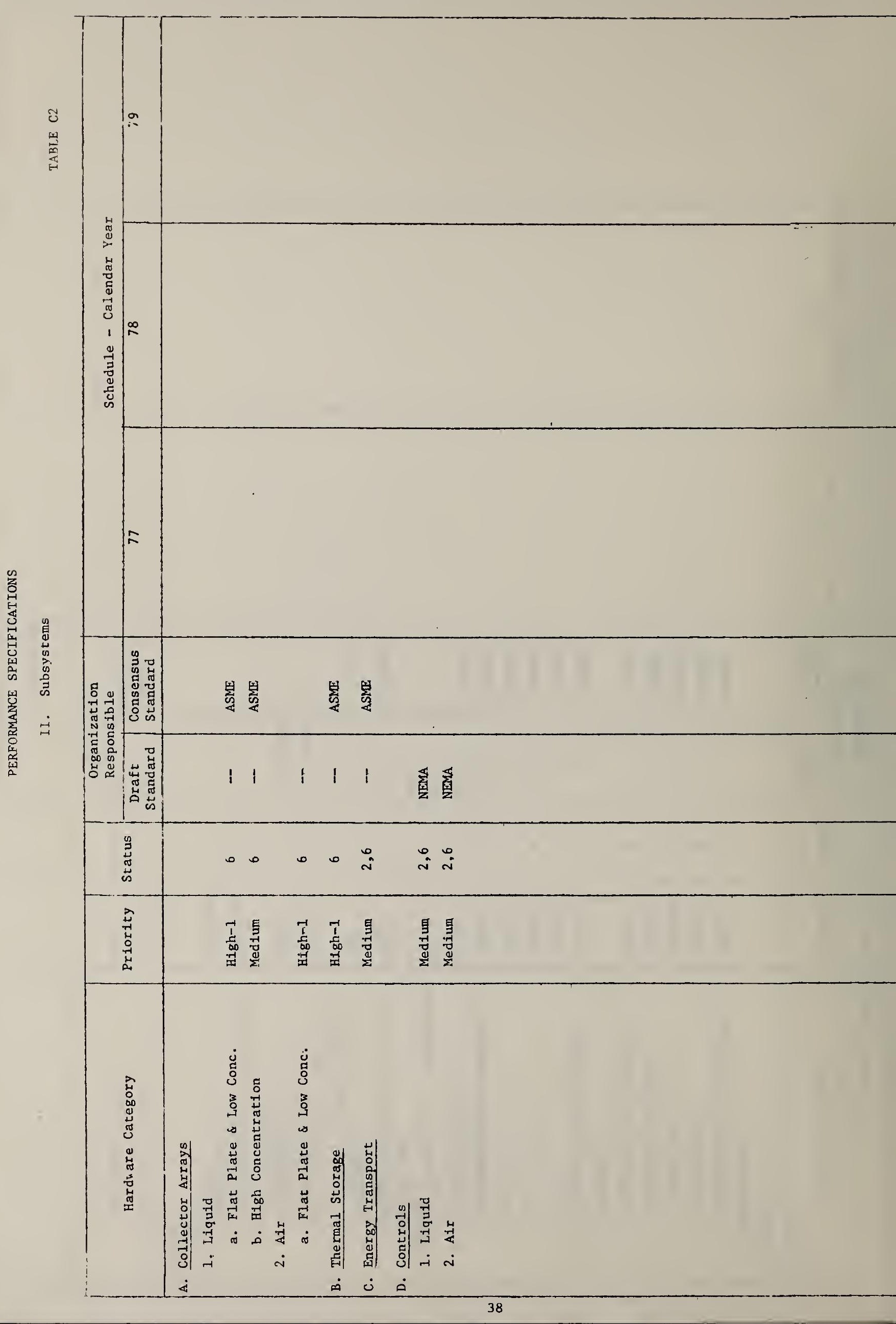




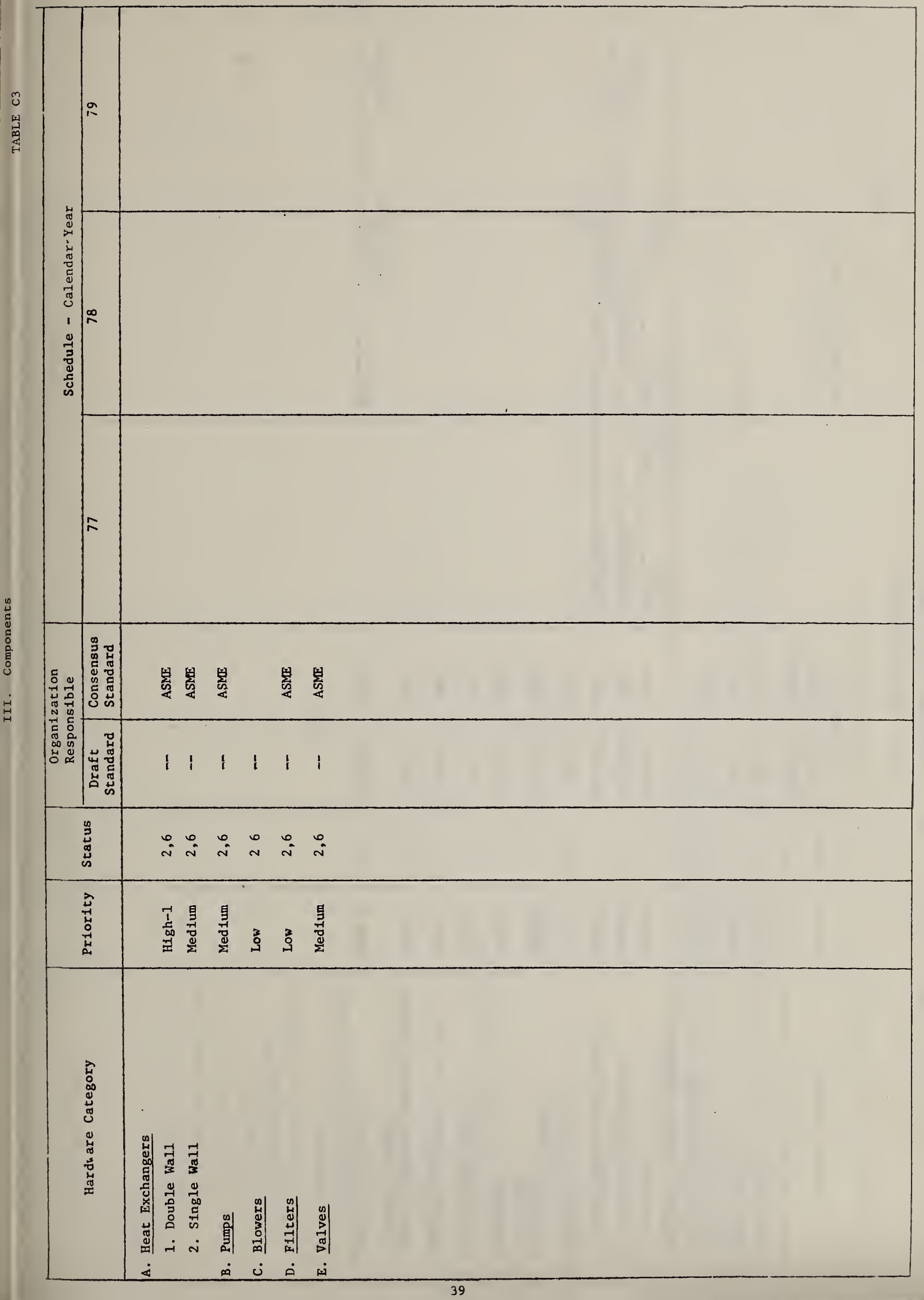




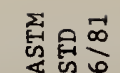

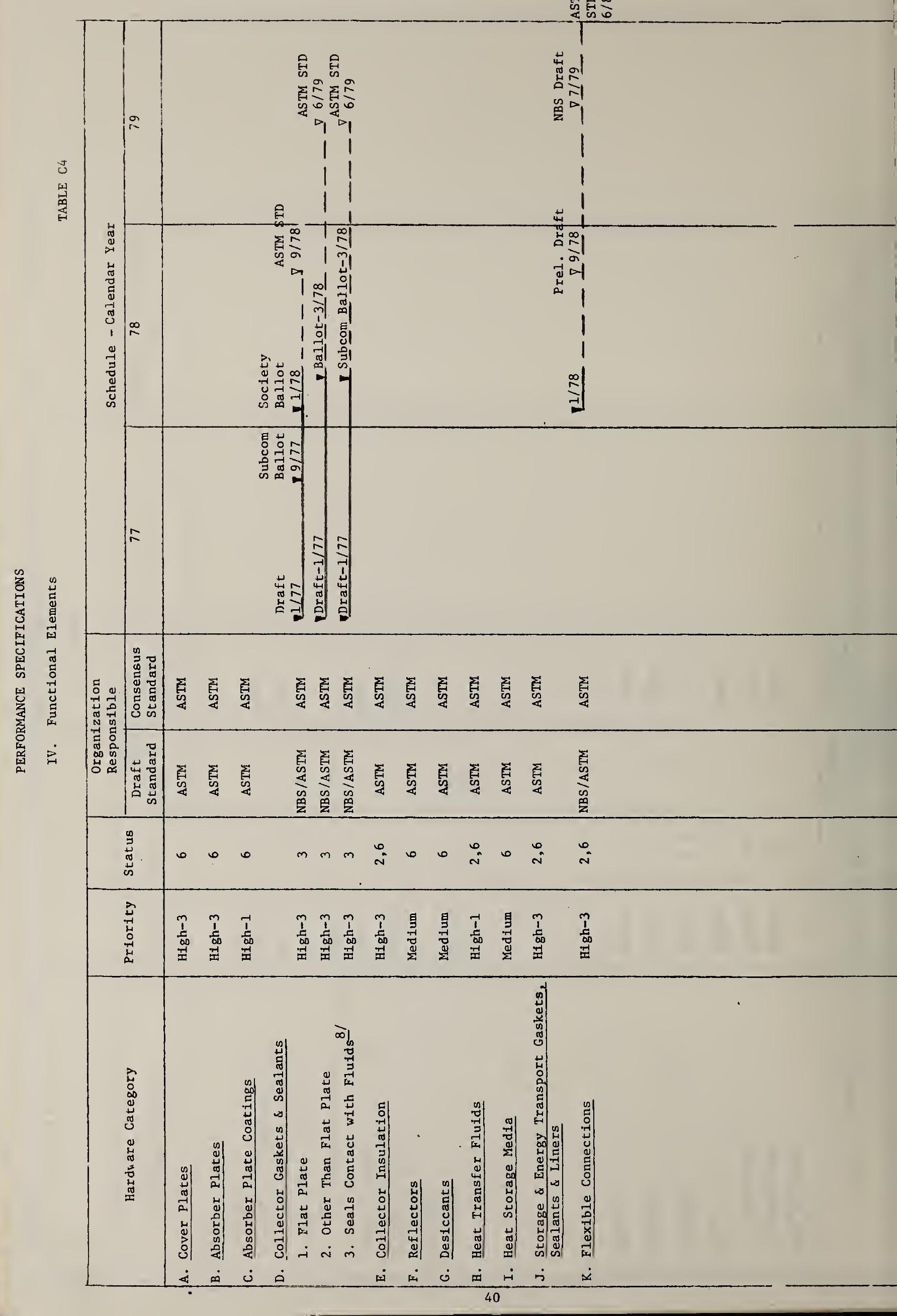




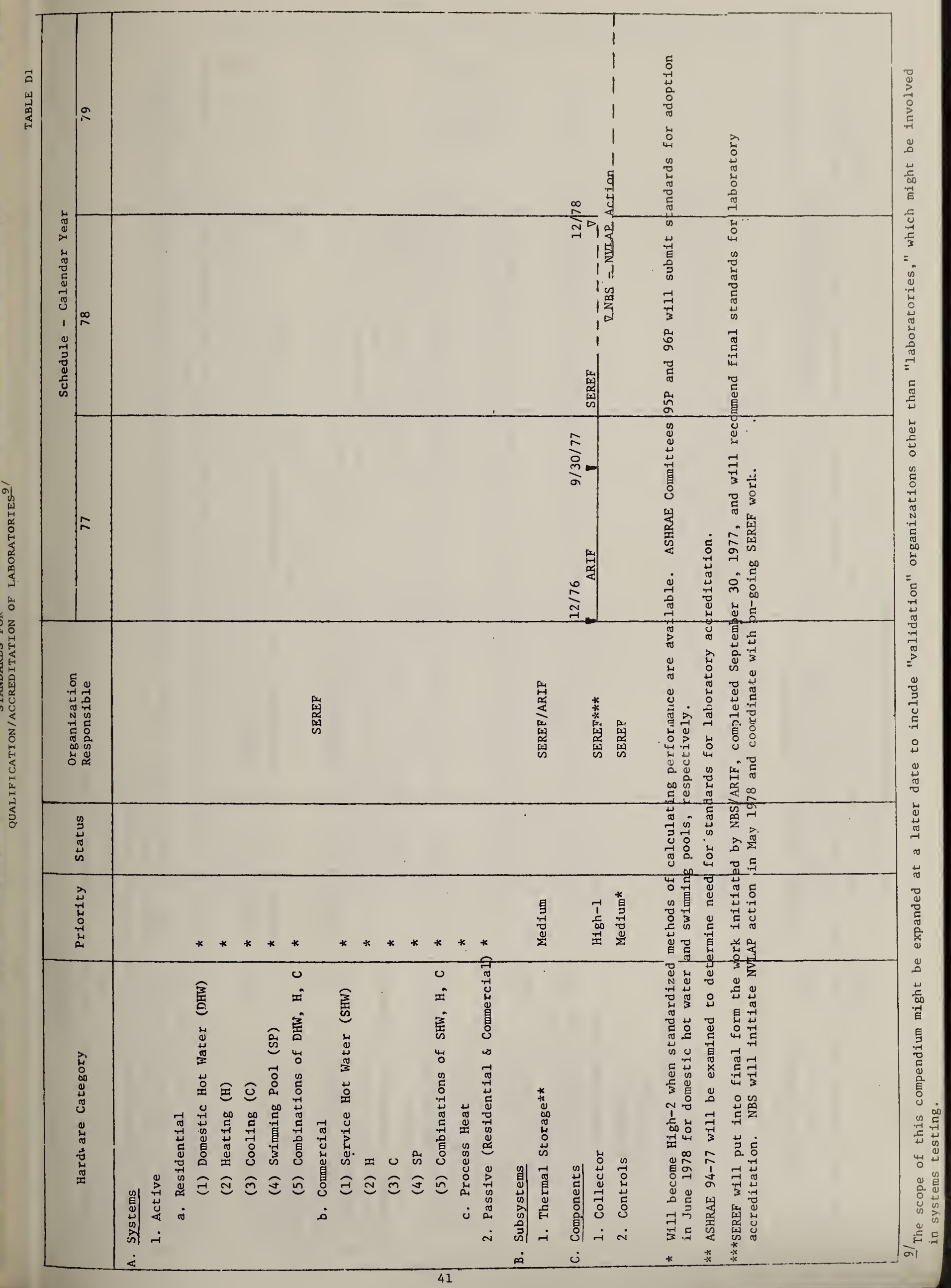




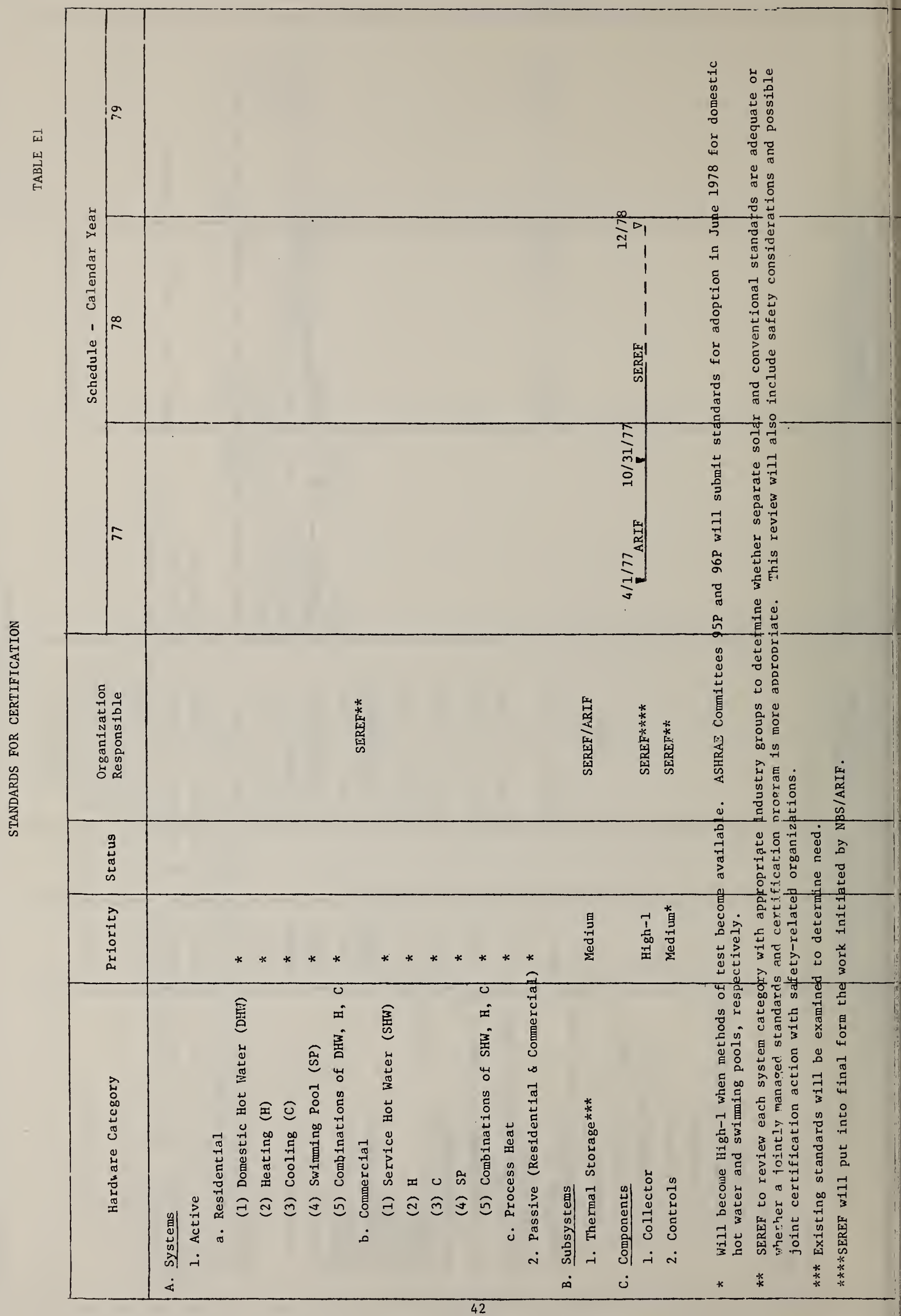




\begin{tabular}{|c|c|c|c|c|c|c|c|c|c|c|}
\hline 窇 & 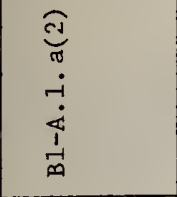 & 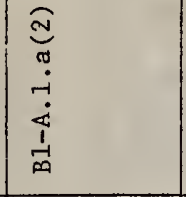 & 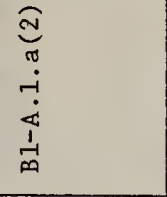 & 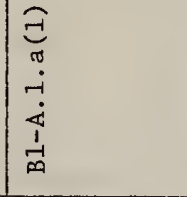 & 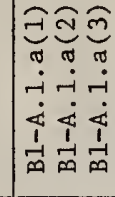 & 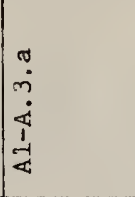 & 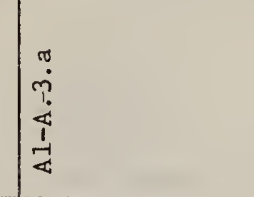 & $\mid$\begin{tabular}{|l}
$\overrightarrow{1}$ \\
$\dot{\alpha}$ \\
$\dot{\alpha}$ \\
$\dot{\alpha}$
\end{tabular} & $\mid \begin{array}{l}\vec{u} \\
\dot{u} \\
\vec{A}\end{array}$ & $\begin{array}{l}\vec{j} \\
\underline{u} \\
\frac{1}{4}\end{array}$ \\
\hline $\begin{array}{c}0 \\
\vdots \\
\vdots \\
\vdots \\
\vdots\end{array}$ & 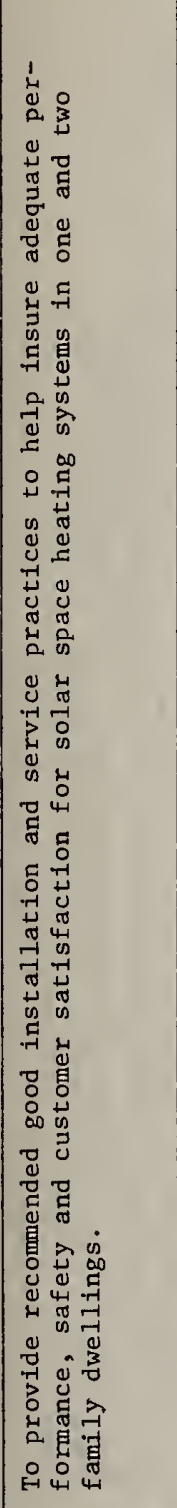 & 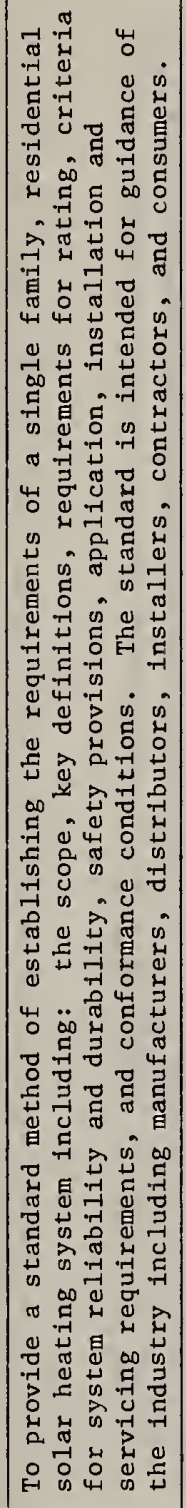 & 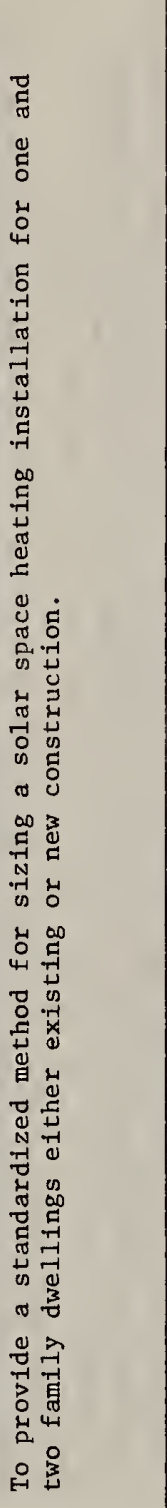 & 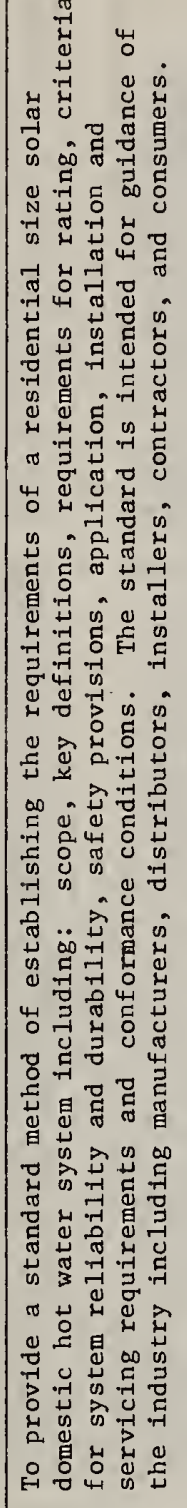 & 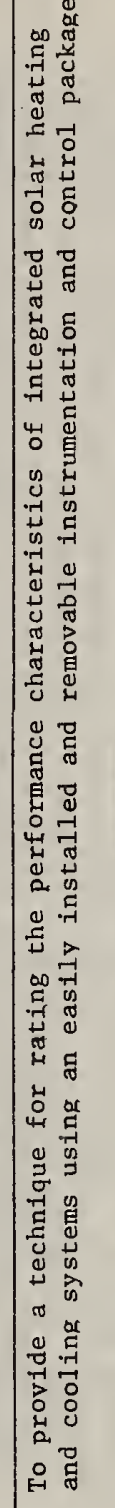 & 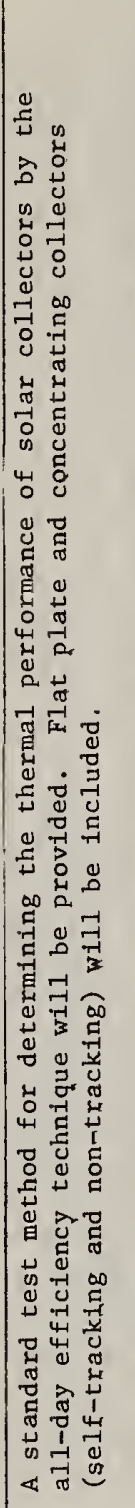 & 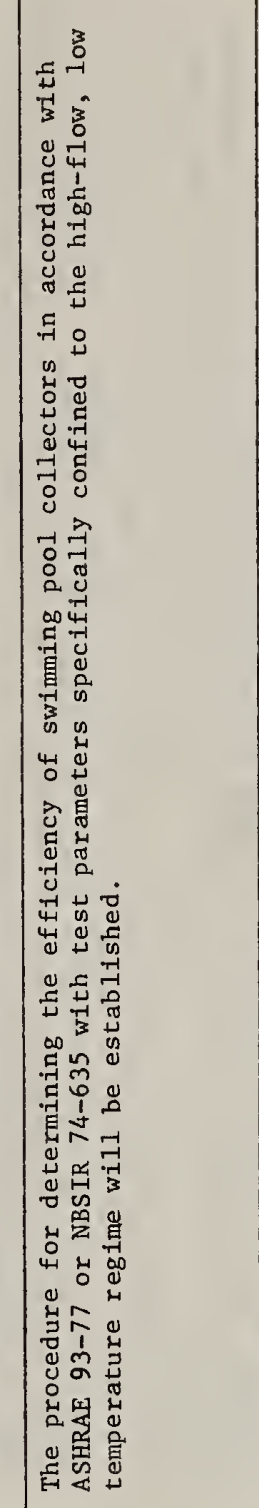 & 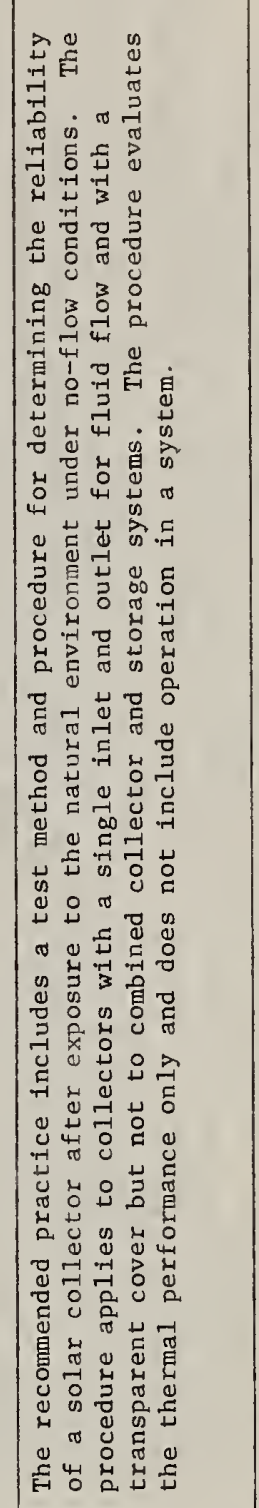 & 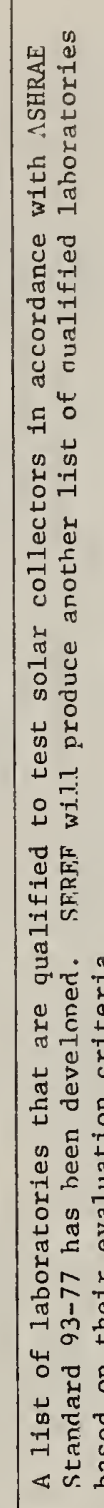 & 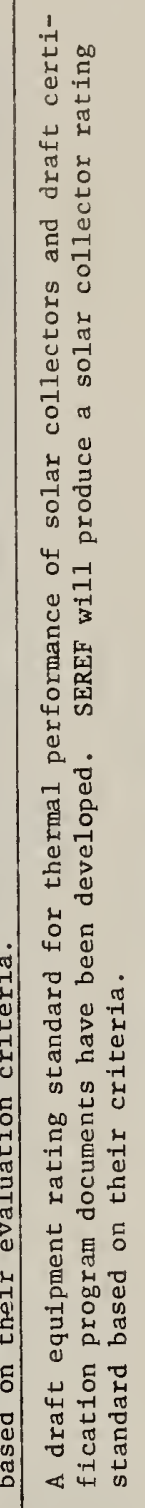 \\
\hline & $\frac{5}{4}$ & 獀 & 牟 & 晿 & 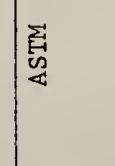 & 志 & 童 & 志 & 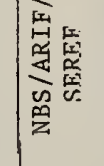 & 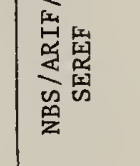 \\
\hline & 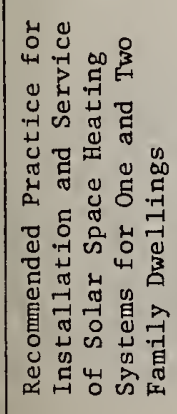 & 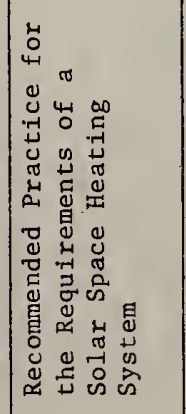 & 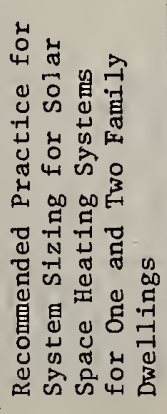 & 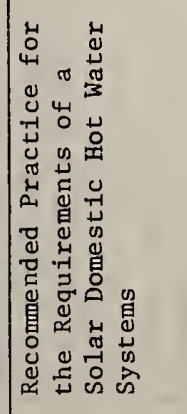 & 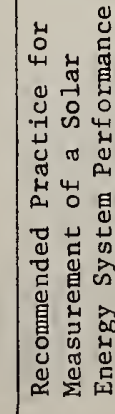 & 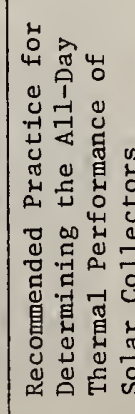 & 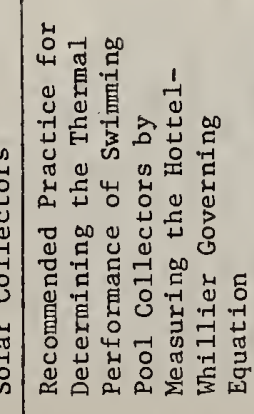 & 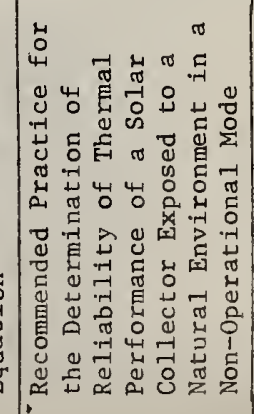 & 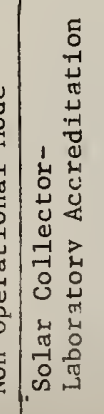 & 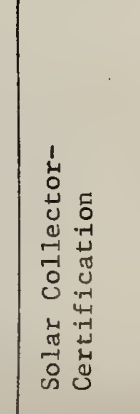 \\
\hline
\end{tabular}




\begin{tabular}{|c|c|c|c|c|c|c|c|c|}
\hline 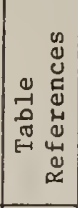 & 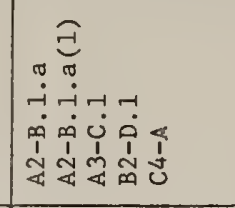 & $\begin{array}{l}\stackrel{\pi}{0} \\
\stackrel{i}{j} \\
i \\
\dot{q}\end{array}$ & 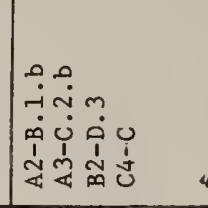 & 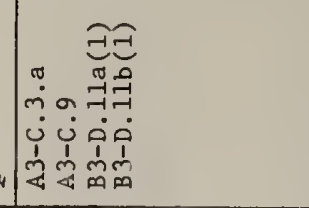 & $\begin{array}{l}\ddot{0} \\
\tilde{u} \\
\dot{j} \\
\tilde{m} \\
4\end{array}$ & 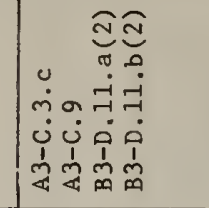 & 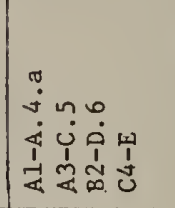 & \begin{tabular}{l}
7 \\
\hdashline \\
0 \\
1 \\
0 \\
$m$ \\
$m$ \\
0
\end{tabular} \\
\hline $\begin{array}{l}\text { o. } \\
\text { : } \\
\text { ஸे }\end{array}$ & 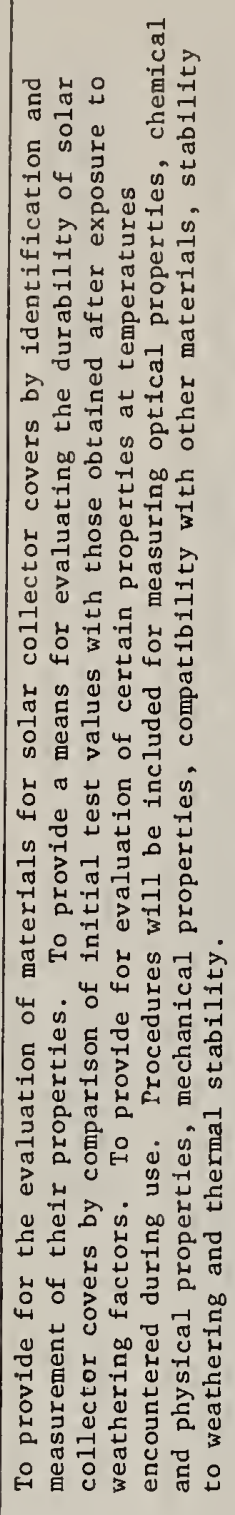 & 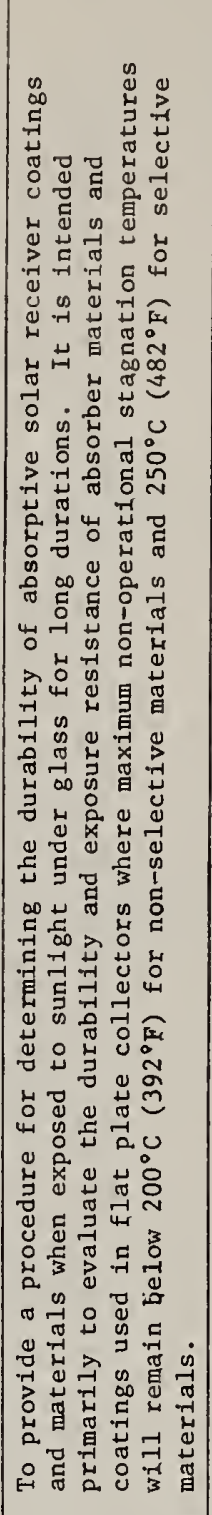 & 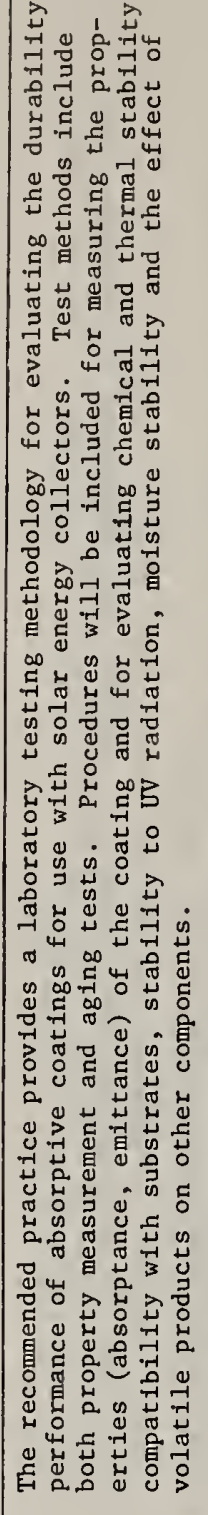 & 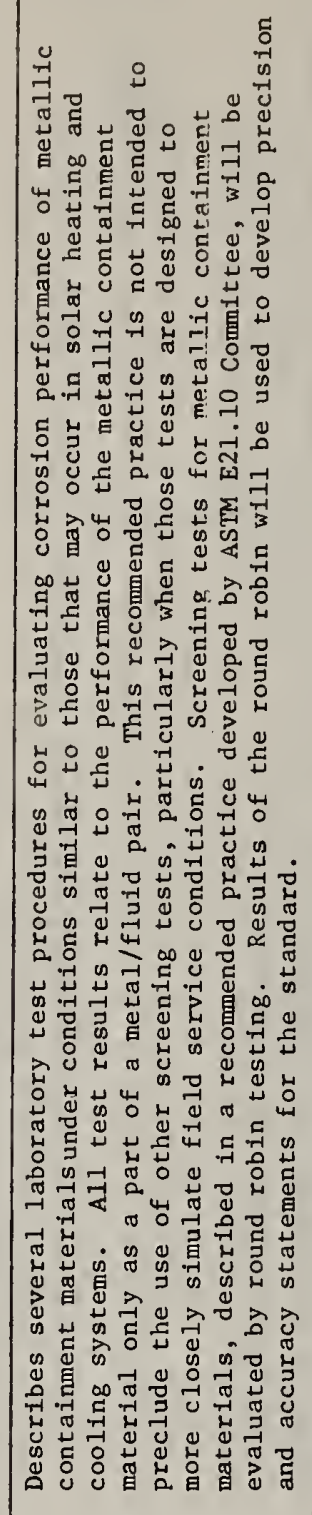 & 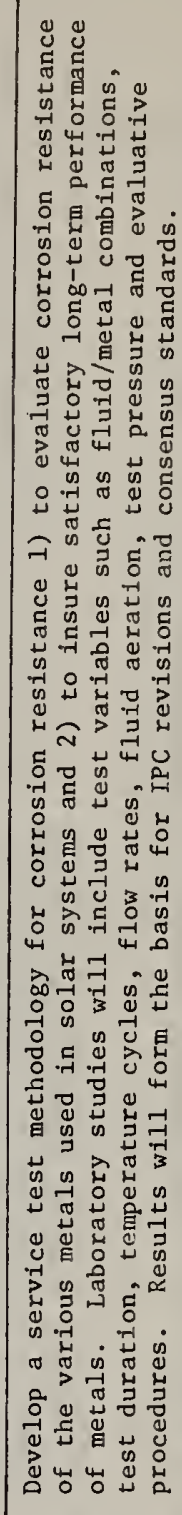 & 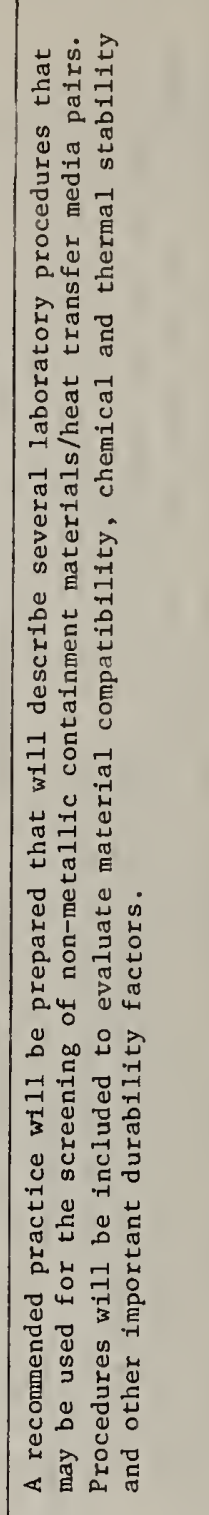 & 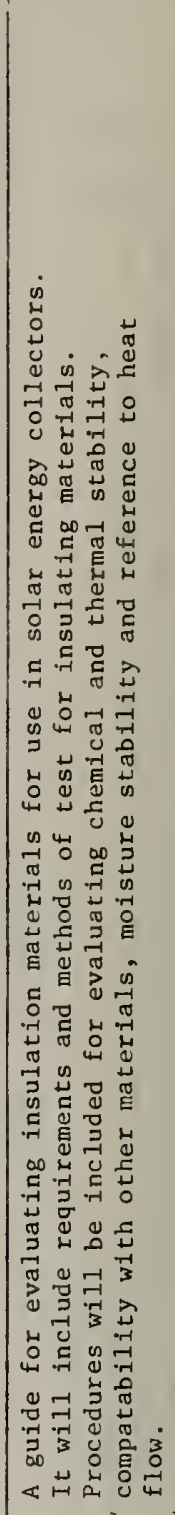 & 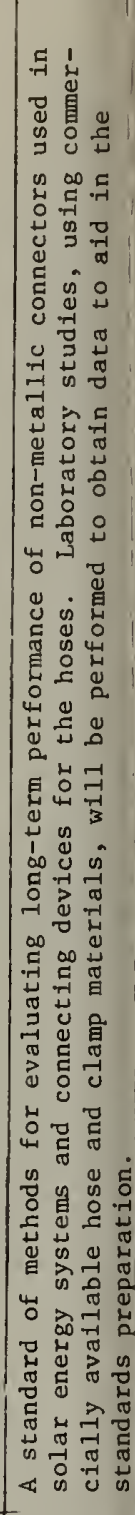 \\
\hline 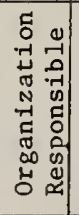 & 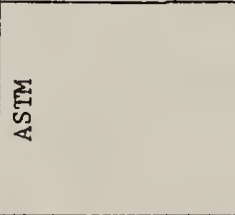 & 站 & 站 & 岁 & 突 & 站 & 毁 & 部 \\
\hline 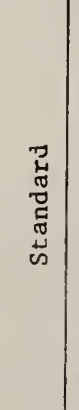 & 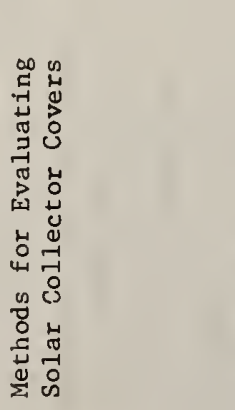 & 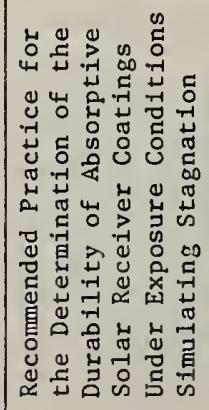 & 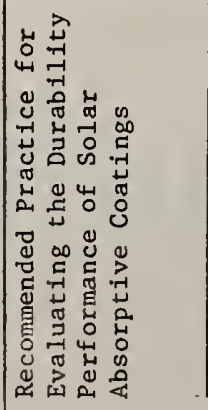 & 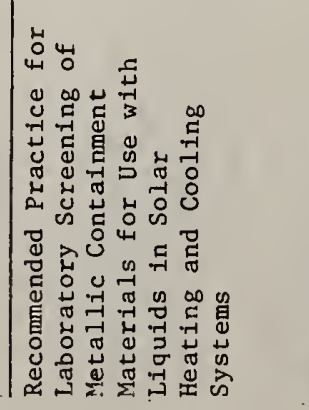 & 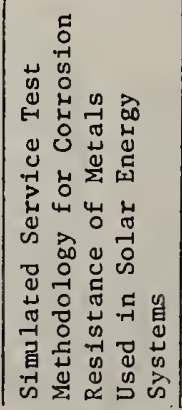 & 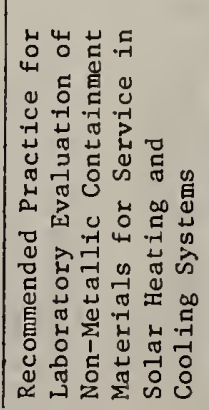 & 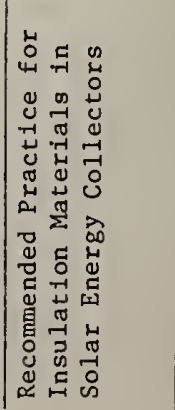 & 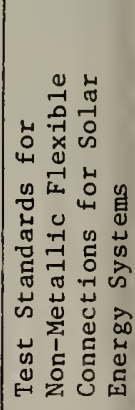 \\
\hline
\end{tabular}




\begin{tabular}{|c|c|c|c|c|c|c|c|}
\hline & 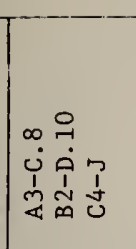 & 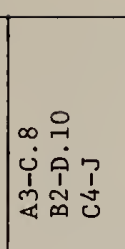 & 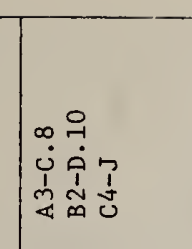 & 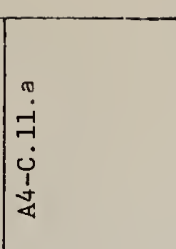 & 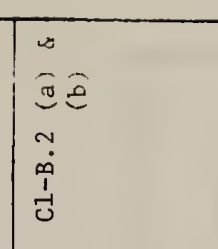 & 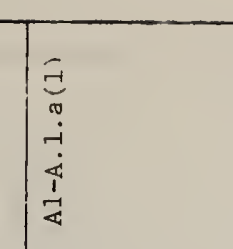 & 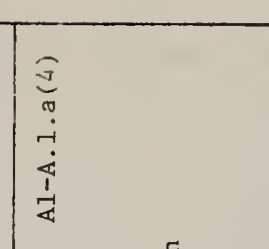 \\
\hline & 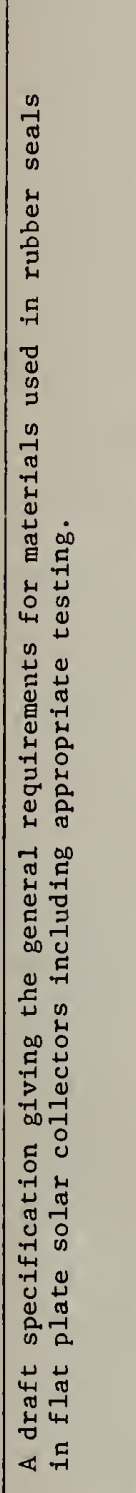 & 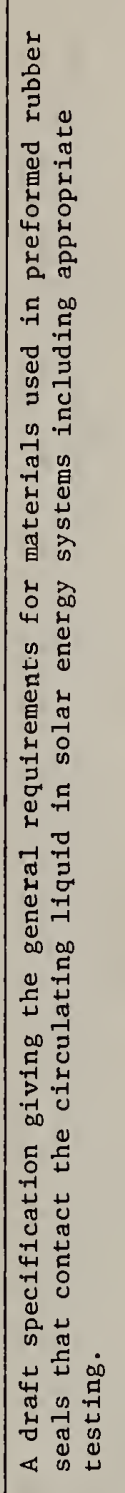 & 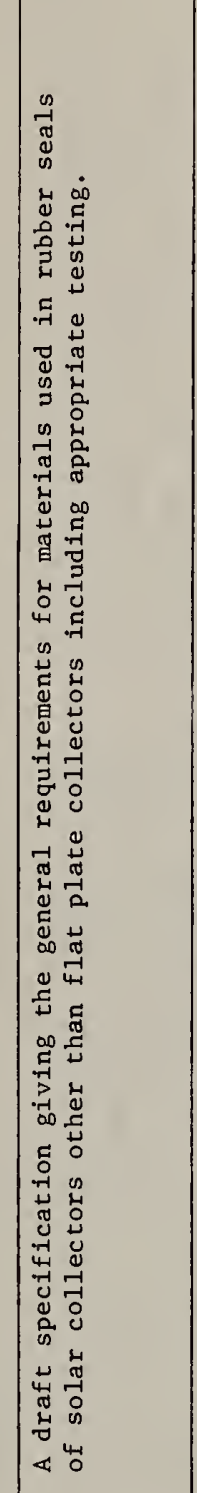 & 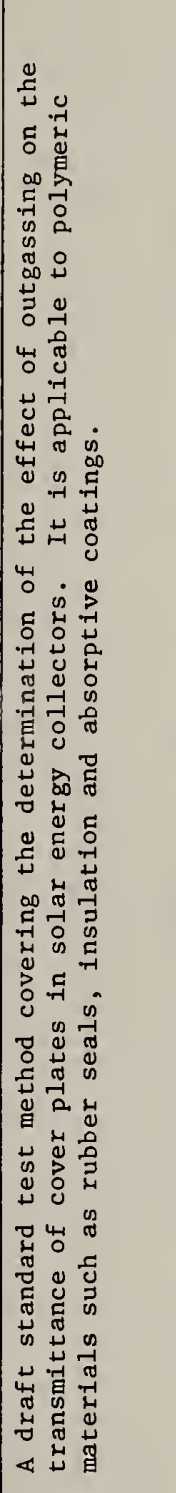 & 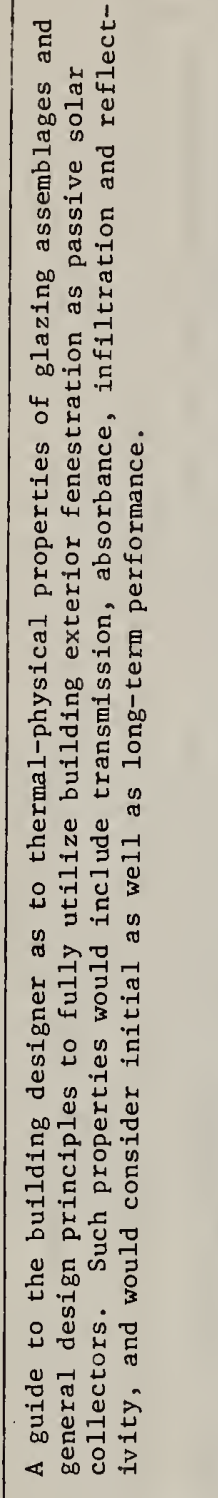 & 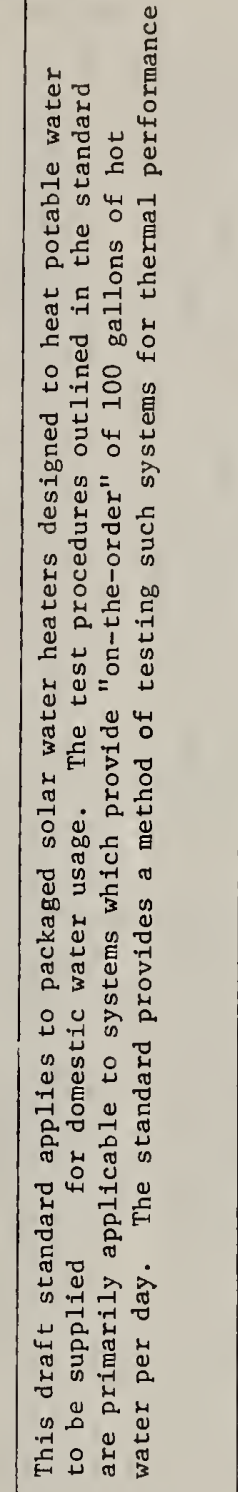 & 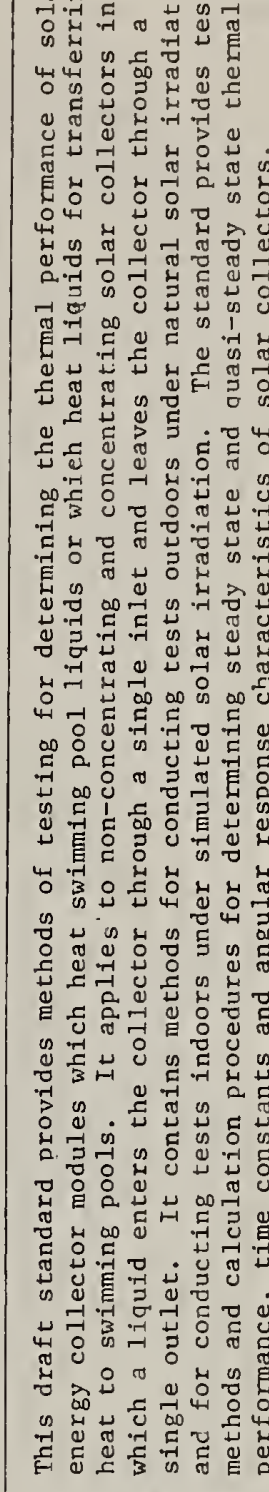 \\
\hline & $\underline{\underline{y}}$ & 晏 & 黑 & $\underline{\underline{z}}$ & $\begin{array}{l}\frac{3}{4} \\
\frac{3}{4} \\
\frac{1}{4}\end{array}$ & 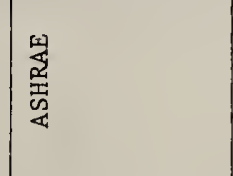 & 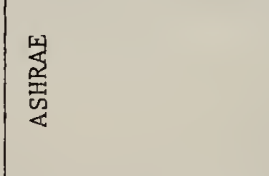 \\
\hline & 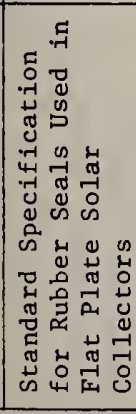 & 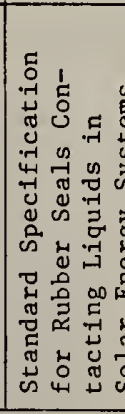 & 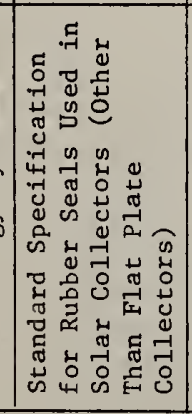 & 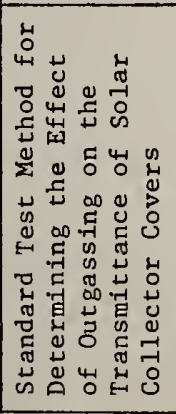 & 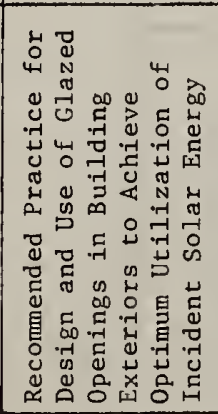 & 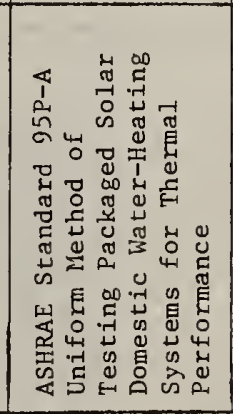 & 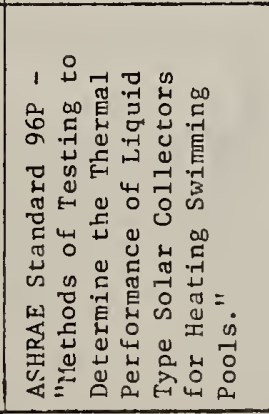 \\
\hline
\end{tabular}




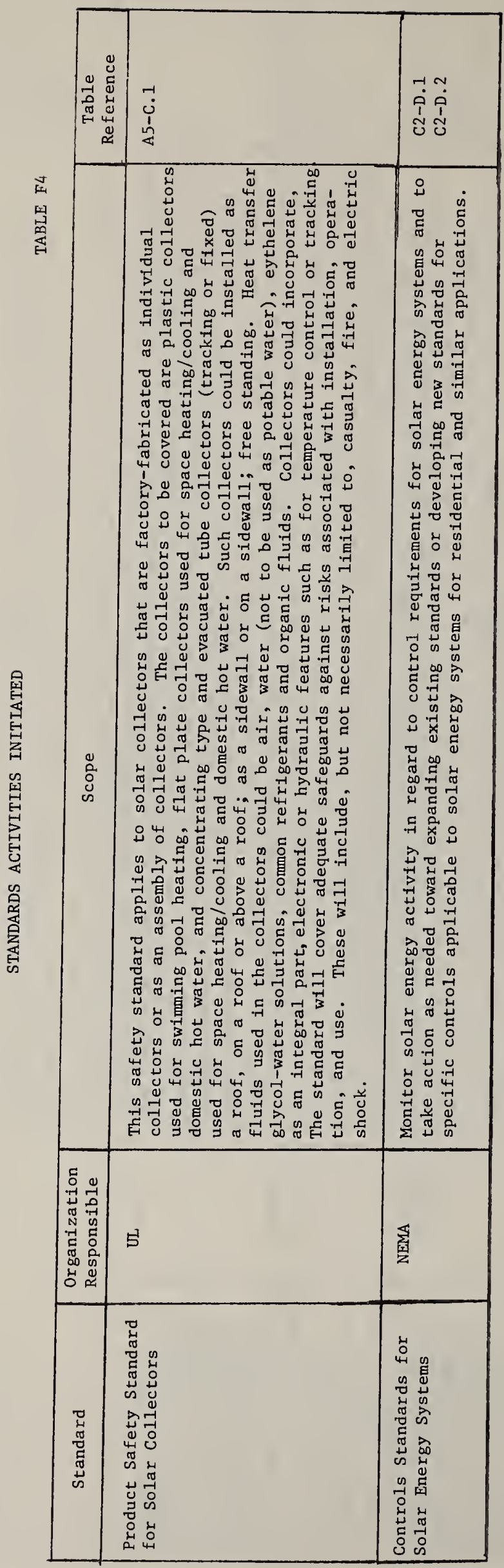




\begin{tabular}{|c|c|c|}
\hline & 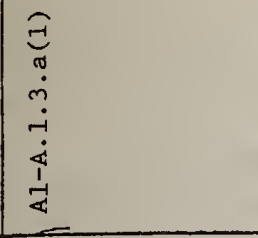 & $\begin{array}{l}\stackrel{\pi}{2} \\
\stackrel{4}{4} \\
\stackrel{1}{4} \\
\end{array}$ \\
\hline 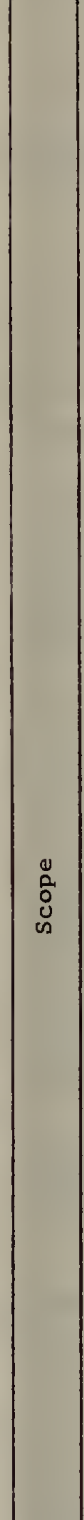 & 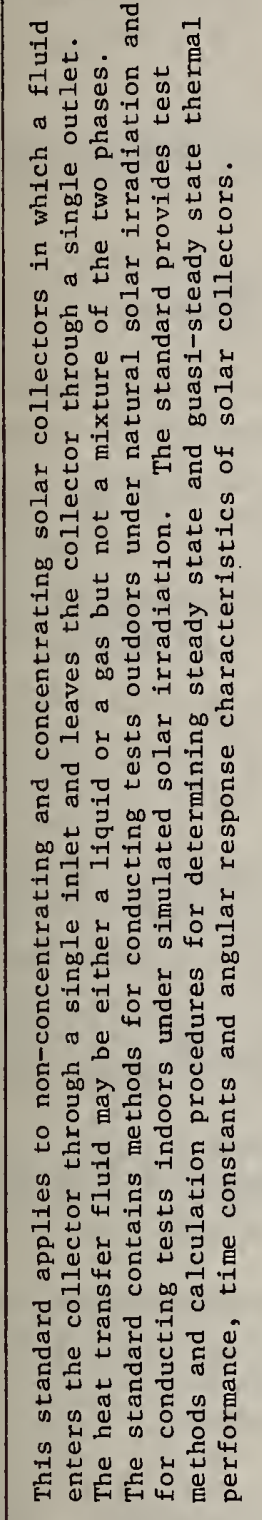 & 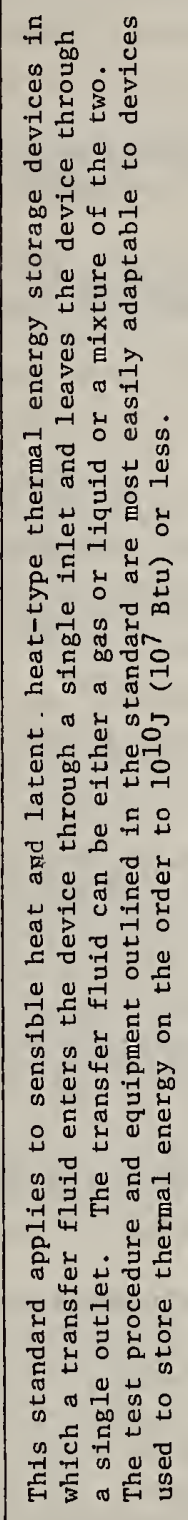 \\
\hline 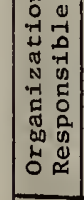 & 嵒 & $\begin{array}{l}\text { 罢 } \\
\text { 恖 }\end{array}$ \\
\hline & 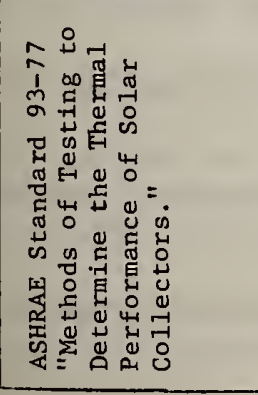 & 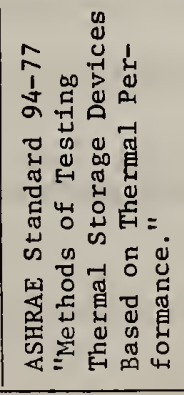 \\
\hline
\end{tabular}


1. "National Program for Solar Heating and Cooling (Residential and Commercial Applications)," ERDA-23A, Energy Research and Development Administration, October 1975.

2. "National Program for Solar Heating and Cooling of Buildings," ERDA 76-6, Energy Research and Development Administration, November 1976.

3. "Solar Heating and Cooling in Buildings - Phase 0," National Science Foundation Reports NSF/RA/N-74-021B, NSF/RA/N-74-022B and NSF/RA/N-74-023B, Washington, D.C., May 1974.

4. Schoen, R., Hirshberg, A. S., and Weingart, J. S., "New Energy Technologies for Buildings," Bollinger Publishing Company, Cambridge, Massachusetts, 1975.

5. "Basic Building Code," (current cdition-1978), Building Officials and Code Administrators International, Inc., Chicago, Illinois 60637

6. "Regulations Governing ASTM Technical Committees", American Society for Testing and Materials, Philadelphia, Pennsylvania, May 1977.

7. "Performance Concept in Buildings, Proceedings of Symposium Jointly Sponsored by RILEM, ASTM and CIB," National Bureau of Standards Special Publication 361, Washington, D.C., February 1972.

8. "The Voluntary Standards System of the United States of America," American Society of Testing and Materials, Philadelphia, Pennsylvania.

9. "HUD Minimum Property Standards, One- and Two-Family Dwellings (No. 4900.1)," U.S. Department of Housing and Urban Development, Washington, D.C. (1973 revised 1974) and "HUD Minimum Property Standards, Multifamily Housing (No. 4910.1)," U.S. Department of Housing and Urban Development, Washington, D.C.

10. "Mobile Home Construction and Safety Standards," U.S. Department of Housing and Urban Development, Federal Register, Part 280, December 18, 1975.

11. "Directory of United States Standardization Activities," National Bureau of Standards Special Publication 417, Washingtọ, D.C. . November 1975.

12. "National Building Code," (current edition-1976), American Insurance Association, New York, New York 10038

13. "Uniform Building Code," (current edition-1976), International Conference of Building Officials, Whittier, California 90601.

14. "Standard Building Code," (current edition-1976), Southern Building Code Congress International, Inc., Birmingham, Alabama 35222

15. "Fire Prevention Code," (current edition-1976), American Insurance Association, New York, New York 10038.

16. "Basic Mechanical Code,"''(current edition-1978), Building Officials and Code Administrators International, Inc., Chicago, Illinois 60637.

17. "Basic Plumbing Code," (current edition-1978), Building Officials and Code Administrators International, Inc., Chicago, Illinois 60637.

18. "Basic Fire Prevention Code," (current edition-1978), Building Officials and Code Administrators International, Inc., Chicago, Illinois 60637.

19. "Standard Mechanical Code," (current edition-1976), Southern Building Code Congress Internationa1, Inc., Birmingham, Alabama 35222 
20. "Standard Plumbing Code," (current edition-1976), Southern Building Code Congress International, Inc., Birmingham, Alabama 35222.

21. "Standard Fire Code," (current edition-1976), Southern Building Code Congress International, Inc., Birmingham, Alabama 35222.

22. "Uniform Fire Code," (current edition-1976), International Conference of Building Offictals, Whittier, California 90601.

23. "Uniform Mechanical Code," (current edition-1976), International Conference of Building Officials, Whittier, California 90601.

24. "Uniform Plumbing Code," (current edition-1976), International Association of Plumbing and Mechanical Officials, Los Angeles, California 90032.

25. "National Electric Code," (current edition-1978), National Fire Protection Agency, Boston, Massachusetts 02210 .

26. Cooke, P. W. and Eisenhard, R. M., "A Preliminary Examination of Building Regulations Adopted by the States and Major Cities," NBSIR 77-1390, National Bureau of Standards, Washington, D.C. 20234, November 1977 (available from NTIS, Order No. PB-274335, price $\$ 6.50)$.

27. "Intermediate Minimum Property Standards for Solar Heating and Domestic Hot Water Systems," NBSIR 77-1226, National Bureau of Standards, Washington, D.C. 20234, March 1977.

28. "Intermediate Standards for Solar Domestic Hot Water Systems/HUD Initiative," NBSIR 77-1272, National Bureau of Standards, Washington, D.C. 20234, July 1977 (available from NTIS, Order No. PB-271758, price $\$ 8.00$ ).

29. "Interim Performance Criteria for Solar Heating and Combined Heating/Cooling Systems and Dwellings," National Bureau of Standards, Washington, D.C., January 1, 1975 (available through Superintendent of Documents, U.S. Government Printing Office, Washington, D.C. 20402, Stock Number 0324-01043).

30. "Interim Performance Criteria for Commercial Solar Heating and Combined Heating/Cooling Systems and Facilities," Document No. 98M1001, George C. Marshall Space F1ight Center, Huntsville, Alabama, February 1975.

31. "Interim Performance Criteria for Solar Heating and Cooling Systems in Commercial Buildings," NBSIR 76-1187, National Bureau of Standards, Washington, D.C., November 1976 (available from NTIS, Order No. PB 262114, price \$5.50).

32. Eisenhard, R. M., "State Solar Energy Legislation of 1976: A Review of Statutes Relating to Buildings," NBSIR 77-1297, National Bureau of Standards, Washington, D.C. 20234, September 1977 (available from NTIS, Order No. PB 273899, price \$10.75).

33. "Performance Standards for Solar Energy Systems and Subsystems Applied to Energy Needs of Buildings [SBC 6101 through 6108]," State of Minnesota Department of Administration, Bullding Code Division, October 1977.

34. "Performance Criteria for Residential Alternative Energy Devices--Solar and Geothermal," State of Oregon Department of Energy, Chapter 330, Temporary Rule, October 1977.

35. "Solar Energy--Criteria for Tax Exemption," Virginia State Board of Housing, October 1977.

36. "Solar Energy Tax Credit--Revised Guidelines and Criteria," Solar office, Alternatives Division, State of California Energy Resources Conservation and Development Commission, March 1978.

37. "Florida Solar Energy Center, Test Methods and Minimum Standards for Solar Collectors," FSEC 77-5, June 1977. 
38. "Methods of Testing to Determine the Thermal Performance of Solar Collectors," ASHRAE Standard 93-77, February 1977, the American Society of Heating, Refrigerating and Air-Conditioning Engineers, 345 East 47th Street, New York, New York 10017.

39. "Methods of Testing Thermal Storage Devices Based on Thermal Performance," ASHRAE Standard 94-77, February 1977, the American Society of Heating, Refrigerating and Air-Conditioning Engineers, 345 East 47th Street, New York, New York 10017.

40. Hill, J. E. and Kusuda, T., "Methods of Testing for Rating Solar Collectors Based on Thermal Performance," NBSIR 74-635, National Bureau of Standards, Washington, D.C. 20234, December 1974 (available from NTIS, Order No. CoM 75-10276, price \$4.25).

41. Kelly, G. E. and Hill, J. E., "Method of Testing for Rating Thermal Storage Devices Based on Thermal Performance," NBSIR 74-634, National Bureau of Standards, Washington, D.C. 20234, May 1975 (avallable from NTIS, Order No. COM 75-10685, price \$4.00).

42. "Uniform Solar Energy Code," September 1976, the International Association of Plumbing and Mechanical Officials, 5032 Alhambra Avenue, Los Angeles, California 90032.

43. "Heating and Air-Conditioning Systems Installation Standards for One and Two Family Dwellings and Multifamily Housing Including Solar," February 1977, the Sheet Metal and Air-Conditioning Contractors National Association, Inc., 8224 0ld Courthouse Road, Tysons Corner, Vienna, Virginia 22180.

44. "Standards and Procedures--Accreditation of Testing Laboratories for Solar Components and Systems," Adopted February 1, 1978, State of Calffornia Energy Resources Conservation and Development Commission, Alternatives Division, Solar Energy Office, 1111 Howe Avenue, Sacramento, California 95825.

45. "Florida Solar Energy Center Operation of the Collector Certification Program," FSEC 77-6, June 1977.

46. "Certification Criteria for Solar Energy Equipment," Preliminary Draft, February 21, 1978, State of California Energy Resources Conservation and Development Commission, Alternatives Division, Solar Energy Office, 1111 Howe Avenue, Sacramento, California 95825.

47. "Report on Organization of Certification Program for Solar Collectors," prepared for NBS by ARI Foundation, Inc., 1815 North Fort Myer Drive, Arlington, Virginia 22209, November 1977.

48. "Manual of Accepted Practices to the HUD Minimum Property Standards (No. 4930.1)," U.S. Department of Housing and Urban Development, Washington, D.C. 20410, 1973. 


$$
\begin{aligned}
& \text { Chairman - Robert D. Dikkers, NBS } \\
& \text { Secretary - Alvin Lai, ANSI }
\end{aligned}
$$

Organization

Air Conditioning and Refrigeration Institute

American Gas Association

American Institute of Architects

American Society of Heating, Refrigerating and Air-Conditioning Engineers

American Society of Mechanical Engineers

\section{American Society for Testing and Materials}

Architectural Aluminum Manufacturers Association

Consumer Action Now's Council on Environmental Alternatives

General Services Administration

Institute of Electrical and Electronics Engineers

International Association of Plumbing and Mechanical officials

Manufactured Housing Institute

Mechanical Contractors Association of America; Inc.

National Aeronautics and Space Administration

National Association of Home Bullders

National Bureau of Standards

Nationa1 Conference of States on Building Codes and Standards

Sheet Metal and Air-Conditioning Contractors' National Association

Representative

Albert Weinstein

G. R. "Monk" Munger

Ronald J. Meyer

Vacant

P. Richard Rittelmann

Michael Holtz

Alvin B. Newton

Joseph F. Cuba

Roger N. Schmidt

George C. Finster

A1len J. Baldwin

William J. Heidrich

Walter V. Cropper

Armen D. Yazujian

Jack M. Roehm

Richard Napoli

James Mackenzie

James A. King

M. Ray Whitley

Robert L. Berg

Vacant

Thomas Highman

Arturo J. Morales

Kenneth T. Springer, Jr. (M)

Henry Omson

Frank Reaves

William C. Abernathy

Orville L. Smith

James D. Hankins

Robert F. Schmitt

Donald Carr

Robert D. Dikkers

David Waksman

Henry Wakabayashi

vacant

Robert G. Mills

Vacant 
Solar Energy Industries Association

Sheldon H. Butt

Vacant

Underwriters Laboratorfes Inc.

Charles B. Schram

(M)

Vacant

U. S. Department of Energy

Ronald D. Scott

(M)

Carl W. Conner

(A)

Alex Haynes

(A)

U. S. Department of Housing and

David Moore

(M) Urban Development

William E. Freeborne

(A)

Member $=(M)$

Alternate $=(\mathrm{A})$ 


\section{List of Building Code Related Organizations}

1. American Insurance Association (AInA)

85 John Street

New York, New York 10038

2. Association of Major City Building Officials (AMCBO)

c/o Public Technology, Inc.

1140 Connecticut Avenue, N.W.

Washington, D.C. 20036

3. Board for the Coordination of the Model Codes (BCMC) c/o CABO

4. Building Officials and Code Administrators International, Inc. (BOCA) 1313 East 60 th Street

Chicago, I11inois 60637

5. Council of American Building Officials (CABO)

560 Georgetown Building

2233 Wisconsin Avenue, N.W.

Washington, D.C. 20007

6. International Conference of Building Officials (ICBO)

5360 South Workman Mill Road

Whittier, California 90601

7. National Research Board (NRB)

c/o either BOCA, ICBO or SBCC

8. Mode1 Code Standardization Council (MCSC)

Secretariat, Building Economics and Regulatory Technology Division

Nationa1 Engineering Laboratory

National Bureau of Standards

Washington, D.C. 20234

9. National Academy of Code Administrators (NACA)

1970 Chain Bridge Road

Clarendon Bank Building

McLean, Virginia 22101

10. National Conference of States on Building Codes and Standards, Inc. (NCSBCS) 1970 Chain Bridge Road

Clarendon Bank Building

McLean, Virginia 22101

11. Southern Building Code Congress International, Inc. (SBCC)

3617 Eighth Avenue South

Birmingham, Alabama 35222

12. International Association of Plumbing and Mechanical Officials (IAPMO) 5032 Alhambra Avenue

Los Angeles, California 90032

13. National Fire Protection Association (NFPA)

470 Atlantic Avenue

Boston, Massachusetts 02210

14. Western Fire Chiefs Association

5360 South Workman Mi11 Road

Whittier, California 90601 



\begin{tabular}{|c|c|c|c|}
\hline $\begin{array}{l}\text { U.S. DEPT. OF COMM. } \\
\text { BIBLIOGRAPHIC DATA } \\
\text { SHEET }\end{array}$ & $\begin{array}{l}\text { 1. PUBLICATION OR REPORT NO. } \\
\text { NBSIR } 78-1143 \AA\end{array}$ & $\begin{array}{l}\text { 2. Gov't Accession } \\
\text { No. }\end{array}$ & 3. Recipient's Accession No. \\
\hline \multirow{2}{*}{\multicolumn{3}{|c|}{$\begin{array}{l}\text { Plan for the Development and Implementation of Standards } \\
\text { for Solar Heating and Cooling Applications }\end{array}$}} & $\begin{array}{l}\text { 5. Publication Date } \\
\text { June } 1978\end{array}$ \\
\hline & & & 6. Performing Organization Code \\
\hline \multicolumn{3}{|c|}{$\begin{array}{l}\text { 7. AUTHOR(S) } \\
\text { D. Waksman, J.H. Niessing } \\
\end{array}$} & 8. Performing Organ. Report No. \\
\hline \multirow{2}{*}{\multicolumn{3}{|c|}{$\begin{array}{l}\text { 9. PERFORMING ORGANIZATION NAME AND ADDRESS } \\
\text { NATIONAL BUREAU OF ST ANDARDS } \\
\text { DEPARTMENT OF COMMERCE } \\
\text { WASHINGTON, D.C. } 20234\end{array}$}} & $\begin{array}{l}\text { 10. Project/Task/Work Unit No. } \\
7446505 \text { Task } 6.1\end{array}$ \\
\hline & & & $\begin{array}{l}\text { 11. Contract/Grant No. } \\
\text { IAA EA-77-A-01-6010 }\end{array}$ \\
\hline \multirow{2}{*}{\multicolumn{3}{|c|}{$\begin{array}{l}\text { 12. Sponsoring Organization Name and Complete Address (Street, City, State, ZIP) } \\
\text { Department of Energy } \\
\text { Office of Conservation and Solar Applications } \\
20 \text { Massachusetts Avenue, NW } \\
\text { Washington, D.C. } 20545\end{array}$}} & $\begin{array}{l}\text { 13. Type of Report \& Period } \\
\text { Covered } \\
\text { Interim }\end{array}$ \\
\hline & & & 14. Sponsoring $A_{\text {gency }}$ Code \\
\hline
\end{tabular}

15. SUPPLEMENTARY NOTES

This is the first revision of NBSIR 76-1143.

16. ABSTRACT (A 200-word or less factual summary of most significant information. If document includes a significant bibliography or literature survey, mention it here.)

The plan, concerning the need, implementation and general scope of standards which may be required for solar heating and cooling applications, has been updated to reflect the progress made in the development of these standards. Overviews of the building regulatory system in the United States are given along with a listing of the various standards which will be required for the various solar systems, subsystems, components and materials. These include Test Method Standards, Recommended Practice Standards and Specification Standards. Activities relative to standards implementation include laboratory accreditation and certification. A list of training activities and manuals of accepted practice is presented. The development of standards for solar applications by the Federal Government are outlined, as well as the potential interface and utilization of the existing consensus standards generating organizations.

17. KEY WORDS (six to twelve entries; alphabetical order; capitalize only the first letter of the first key word unless a proper name; separated by semicolons)

Buildings; solar energy; standards

18. AVAILABILITY $\mathrm{XX}$ Unlimited

For Official Distribution. Do Not Release to NTIS

Order From Sup. of Doc., U.S. Government Printing Office Washington, D.C. 20402, SD Cat. No.CI3

X. Order From National Technical Information Service (NTIS) Springfield, Virginia 22 I5I

\begin{tabular}{|c|c|}
\hline $\begin{array}{l}\text { 19. SECURITY CLASS } \\
\text { (THIS REPURT) } \\
\text { UNCL ASSIFIED }\end{array}$ & $\begin{array}{l}\text { 21. NO. OF PAGES } \\
58\end{array}$ \\
\hline $\begin{array}{l}\text { 20. SECURITY CLASS } \\
\text { (THIS PAGE) } \\
\text { UNCLASSIFIED }\end{array}$ & $\begin{array}{l}\text { 22. Price } \\
\$ 5.25\end{array}$ \\
\hline
\end{tabular}


